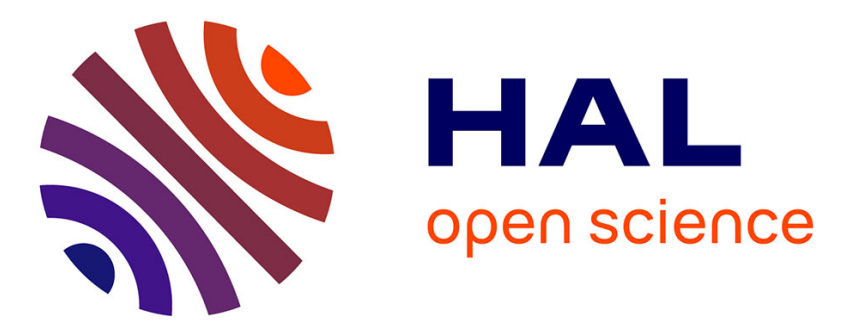

\title{
DFT-Based Cu(111)\|Cu2O(111) Model for Copper Metal Covered by Ultrathin Copper Oxide: Structure, Electronic Properties, and Reactivity
}

Fatah Chiter, Dominique Costa, Vincent Maurice, Philippe Marcus

\section{- To cite this version:}

Fatah Chiter, Dominique Costa, Vincent Maurice, Philippe Marcus. DFT-Based $\mathrm{Cu}(111) \| \mathrm{Cu} 2 \mathrm{O}(111)$ Model for Copper Metal Covered by Ultrathin Copper Oxide: Structure, Electronic Properties, and Reactivity. Journal of Physical Chemistry C, 2020, 124 (31), pp.17048-17057. 10.1021/acs.jpcc.0c04453 . hal-02909752

\section{HAL Id: hal-02909752 https://hal.science/hal-02909752}

Submitted on 31 Jul 2020

HAL is a multi-disciplinary open access archive for the deposit and dissemination of scientific research documents, whether they are published or not. The documents may come from teaching and research institutions in France or abroad, or from public or private research centers.
L'archive ouverte pluridisciplinaire HAL, est destinée au dépôt et à la diffusion de documents scientifiques de niveau recherche, publiés ou non, émanant des établissements d'enseignement et de recherche français ou étrangers, des laboratoires publics ou privés. 


\title{
A DFT-Based $\mathrm{Cu}(111) \| \mathrm{Cu}_{2} \mathrm{O}(111)$ Model for Copper Metal Covered by Ultrathin Copper Oxide: Structure, Electronic Properties and Reactivity
}

\author{
Fatah Chiter, ${ }^{*}$ Dominique Costa, ${ }^{*}$ Vincent Maurice, and Philippe Marcus \\ PSL University, CNRS - Chimie ParisTech, Institut de Recherche de Chimie \\ Paris/Physical Chemistry of Surfaces Group, 11 rue Pierre et Marie Curie, 75005 Paris,
} France

E-mail: fatah.chiter@chimieparistech.psl.eu; dominique.costa@chimieparistech.psl.eu

\begin{abstract}
In many applications, metallic copper can be covered by an ultrathin native or a passive oxide film depending on the redox conditions of the interface formed with the environment, which governs its surface properties. In the present work, we constructed and optimized through quantum chemical DFT calculations a model of this $\mathrm{Cu}(111) \| \mathrm{Cu}_{2} \mathrm{O}(111)$ stoichiometric oxide supported in parallel epitaxy on $\mathrm{Cu}(111)$ substrate. Energetic analysis of the metal-oxide interface shows the stable formation of the interface between oxide film and metal substrate. The $\mathrm{Cu}_{2} \mathrm{O}(111)$ film binds to the $\mathrm{Cu}(111)$ surface via the unsaturated oxygen atoms bonded to copper metal atoms in top, bridge and hollow sites. Structural analysis of the $\mathrm{Cu}_{2} \mathrm{O}(111)$ film surface shows reconstruction with modifications of the distances between the unsaturated and the saturated copper atoms. The surface interlayer relaxation is inward for
\end{abstract}


$\mathrm{Cu}(111) \| \mathrm{Cu}_{2} \mathrm{O}(111)$, whereas it is outward for the non supported $\mathrm{Cu}_{2} \mathrm{O}(111)$ oxide, and converges to that of bulk oxide with increasing the $\mathrm{Cu}_{2} \mathrm{O}(111)$ thickness. The electronic work function is not significantly modified with respect to the $\mathrm{Cu}(111)$ electronic work function, whatever the oxide thickness. The hydration of the surface is energetically favorable and water molecular adsorption is favored over dissociative adsorption. Water molecules chemisorb on top over unsaturated copper atoms. The hydroxylation of the surface shows two adsorption modes of the $\mathrm{OH}$ groups on top over unsaturated $\mathrm{Cu}$ atoms and on bridge site between unsaturated and saturated $\mathrm{Cu}$ atoms.

\section{Introduction}

The formation, chemical composition and structure of a surface oxide film is crucial in important technological processes based on surface properties, such as corrosion protection, ${ }^{1}$ energy conversion ${ }^{2}$ and catalysis. ${ }^{3,4}$ The presence, composition and structure of an oxide overlayer on metallic substrate is determined by the redox conditions of the interface formed with the environment. On copper in aqueous environmental conditions, the formation of a protective anodic oxide depends on the nature of the electrolyte, $\mathrm{pH}$, potential of solid-liquid interface, immersion and polarization time.

For some decades theoretical works have been performed to better understand the structure of metal surfaces and their electronic properties and reactivity for a variety of application domains, ${ }^{5-7}$ ranging from heterogeneous catalysis to corrosion protection. One of the prerequisite conditions for a relevant theoretical approach is that the modeled system is representative of the experimental conditions. For surfaces, the chemical and structural state of the surface layers plays a key role in the reactivity and it is mandatory to model properly the surface terminations.

In the case of copper, the surface has been shown to be in the metallic state in acidic solutions $(\mathrm{pH}<5),{ }^{8,9}$ due to the fast dissolution of the oxide, and also in alkaline solutions in the underpotential range of $\mathrm{Cu}_{2} \mathrm{O}$ formation. This has been observed in $1 \mathrm{mM} \mathrm{K}_{2} \mathrm{SO}_{4}$ 
alkaline solution of $\mathrm{pH} 8$ or 10 at potential $\mathrm{E}<-0.90 \mathrm{~V},{ }^{10}$ in $0.1 \mathrm{M} \mathrm{NaOH}$ solution of pH 13 at $-0.675 \pm 0.02 \mathrm{~V} / \mathrm{SHE}^{11}$ and at potential $\mathrm{E}<-0.75 \mathrm{~V} \cdot{ }^{12}$ Under these conditions, a theoretical model composed of a $\mathrm{Cu}(\mathrm{hkl})$ metal slab is appropriate to investigate adsorbatecopper interactions at the atomic scale. ${ }^{12,13}$

In contrast, at $\mathrm{pH}>5$ and in the overpotential range of copper oxide formation, copper is covered by an anodic oxide film of $\mathrm{Cu}_{2} \mathrm{O}$ or $\mathrm{Cu}_{2} \mathrm{O} / \mathrm{CuO}$ depending on potential. This oxide film is generally ultrathin, ranging from 1 to $4 \mathrm{~nm}$ depending on the experimental conditions. The oxide thickness has been estimated experimentally to be $<4 \mathrm{~nm}$ in $0.1 \mathrm{M}$ $\mathrm{KOH}$ alkaline solution, ${ }^{14} 2.2 \pm 0.3 \mathrm{~nm}$ in 3 wt. $\% \mathrm{NaCl}$ neutral solution ${ }^{15}$ and to not exceed $1.4 \mathrm{~nm}$ in $0.1 \mathrm{M}$ phosphate buffer solution of $\mathrm{pH} 7$ and 8 and in borax buffer solution of $\mathrm{pH}$ 9.2. ${ }^{16}$ In $0.1 \mathrm{M} \mathrm{NaOH}$ solution of $\mathrm{pH} 13$, at potential $\mathrm{E}=0.75,1,17$ a duplex film is formed on $\mathrm{Cu}(111)$, with an inner layer of $\mathrm{Cu}_{2} \mathrm{O}(111)$ oxide 1-1.6 nm thick and a mixed outer layer of $\mathrm{CuO} / \mathrm{CuOH}$ about $2-4 \mathrm{~nm}$ thick. At potential $\leq-0.25 \mathrm{~V}$, the thickness of $\mathrm{Cu}_{2} \mathrm{O}$ is below 7 monolayers. $^{1,5}$

In order to describe the available experimental data at the atomic scale with theoretical models of the oxidized surface, several groups used non supported $\mathrm{Cu}_{2} \mathrm{O}(111)$ oxide surfaces, ${ }^{18-20}$ obtained by cleavage of the bulk $\mathrm{Cu}_{2} \mathrm{O}$ oxide structure. This approach is adequate when the oxide on top of the metal is thick enough to have the electronic properties of the bulk oxide. Therefore, one can neglect the underling metal part and only investigate the adsorbate-oxide surface interactions.

This theoretical modeling approach may not be appropriate to study the adsorbatesubstrate interactions when copper is covered by an ultrathin oxide layer. Most of the theoretical models of oxidized copper found in the literature which are related to the formation of the oxide on the copper metal are focused on the adsorption of oxygen on the $\mathrm{Cu}(111)$ surface. Using a model consisting of a $\mathrm{Cu}(111)$ slab covered by a single $\mathrm{CuOx}$ oxide layer, ${ }^{21}$ Gharachorlou et al. have shown that TMA (trimethylaluminum) adsorption occurs on oxidized $\mathrm{Cu}$ but not on metallic $\mathrm{Cu}$. Using DFT, An et al. ${ }^{22}$ have shown that 
the deposition of potassium impacts the surface electronic structure with a $\mathrm{CuxO} / \mathrm{Cu}(111)$ $(\mathrm{x} \leq 2)$ model and the results agreed with STM measurements. The structural model for the "29" -structure of $\mathrm{CuxO} / \mathrm{Cu}(111)$ was studied by DFT and STM techniques over a range of scanning biases. ${ }^{23,24}$ The "29" oxide acts as a precursor to bulk oxidation and the phase diagram shows that when the $\mathrm{O}$ chemical potential is high enough, bulk $\mathrm{Cu} 2 \mathrm{O}(111)$ oxide formation takes place and it is the preferred species. ${ }^{23}$ Park et al. studied the adsorption of molecular fragments of pyromellitic dianhydride oxydianiline (PMDA-ODA) on pristine and mildly oxidized $\mathrm{Cu}(111)$ surfaces. ${ }^{25} \mathrm{~A}$ model based on the mismatch-overlayer structure of the (111) faces of $\mathrm{Cu}_{2} \mathrm{O}$ and the $\mathrm{Cu}$ was proposed by Jensen et al. ${ }^{26}$ Yang et al. ${ }^{27}$ used the structural model of the $\mathrm{Cu}_{2} \mathrm{O}(111)$-like monolayer on $\mathrm{Cu}(111)$, with two types of oxygen species, chemisorbed oxygen and lattice oxygen within $\mathrm{Cu}_{2} \mathrm{O}$. Soon et al. ${ }^{28}$ studied the chemisorption of oxygen and the thermodynamic stability of the surface oxide on $\mathrm{Cu}(111)$. Their phase diagram $(\mathrm{P}, \mathrm{T})$, shows that the oxygen proceeds directly to the formation of a surface oxide structure and to the bulk oxide phase, which is in the line with experimental observation.

The growth and surface properties of cuprous oxide films depend on the support used. ${ }^{29-32}$ The underlying metal layers can impose a strain to the oxide surface that can affect the surface reactivity of the ultrathin copper oxide film. The oxide thickness can affect the reactivity. ${ }^{33}$ In the presence of an adsorbate, the growth of the oxide layer can be limited. An XPS surface analysis revealed that the chemical surface state of the copper surface is very different in the absence or presence of a self-assembled monolayer of 4-fluorobenzenethiol (4-F-BT) pre-adsorbed on copper. ${ }^{34}$ Without pre-adsorption the surface is typical of $\mathrm{CuO}$ and $\mathrm{Cu}(\mathrm{OH})_{2}$, whereas after 4-F-BT pre-adsorption, it shows the absence of $\mathrm{Cu}^{2+}$ and suggests the possible presence of $\mathrm{Cu}_{2} \mathrm{O}$ traces as inferred from the analysis of the $\mathrm{Cu}$ Auger spectra at $570.4 \mathrm{eV}$. Recently, the pre-adsorption of 2-mercaptobenzothiazole (MBT) and 2-mercaptobenzimidazole (MBI) corrosion inhibitors at ultra low pressure on $\mathrm{Cu}(111)$ has been shown to markedly retard the oxidation kinetics. ${ }^{35-37}$ 
The choice of the metal/oxide interface model is of outermost importance, as many properties including corrosion resistance are related to the composition and electronic properties of this interface. ${ }^{29}$ So, it is very important to elaborate the most realistic interfacial model. This is the reason why we have recently used a model of oxidized $\mathrm{Cu}$ consisting of $\mathrm{Cu}_{2} \mathrm{O}(111)$ in parallel epitaxy on $\mathrm{Cu}(111)$, in order to study by Density Functional Theory (DFT) the adsorption of MBT, a known corrosion inhibitor, on the oxidized copper surface. ${ }^{38}$

Here we detail the construction of this epitaxial $\mathrm{Cu}(111) \| \mathrm{Cu}_{2} \mathrm{O}$ model. We discuss the construction of the model, the oxide/metal interface, the oxide surface relaxation and the electronic properties. The reactivity with water and $\mathrm{OH}$ groups is also studied and compared to results obtained on non supported $\mathrm{Cu}_{2} \mathrm{O}(111)$ oxide surfaces from the literature.

\section{Methods}

DFT was used with the periodic plane-wave basis set code VASP (Vienna Ab initio Simulation Package). ${ }^{39-42}$ All results reported have been obtained with projector-augmented-wave potentials using a $450 \mathrm{eV}$ plane-wave cut-off. ${ }^{43,44}$ The Generalized Gradient Approximation (GGA) of Perdew-Burke-Ernzehof (PBE) functional was used for the exchange-correlation term. ${ }^{45,46}$ We used a Methfessel-Paxton smearing. ${ }^{47}$ After preliminary calculations on the metal and oxide bulk structures, we opted for the Van der Waals contributions in the local van der Waals density functional scheme proposed by Dion et $\mathrm{al}^{48}$ and Klimeŝ et $\mathrm{al}^{49-51}$ and calculations were carried out using OptB86b-vdw level. ${ }^{50}$ The Brillouin-zone sampling was restricted to the $\Gamma$-point, ${ }^{52}$ due to the large supercell size used in the calculations. The supercell consists of four layers of copper metal oriented (111) covered by two to six stoichiometric $\mathrm{Cu}_{2} \mathrm{O}(111)$ layers yielding a thickness varying from 5.89 to $16.24 \AA$. The vacuum region was set at more than $18 \AA$ to minimize the interactions in the $\mathrm{z}$ direction between periodic images of the system. Optimizations were performed with restricted spin. The molecules $\left(\mathrm{H}_{2} \mathrm{O}\right.$ and $\mathrm{OH}^{\circ}$ group) were adsorbed on top of the oxide layer. To calculate the energies of 
the molecules in the gas phase, they were optimized in vacuum in a cell of $20 \AA \times 20 \AA \times 20 \AA$ dimensions. The adsorbates, all layers of the oxide film and the two uppermost layers of the copper metal were allowed to move freely, and the two bottom layers of the metal were fixed. Atomic positions were relaxed with the conjugate gradient (CG) algorithm until forces on each moving atom were less than $0.02 \mathrm{eV}^{-1}$.

\section{Energetic}

The cohesion energy of the $\mathrm{Cu}_{2} \mathrm{O}(111)$ oxide on the $\mathrm{Cu}(111)$ metal was calculated as:

$$
E_{\text {cohesion }}=(E(\text { metal })+E(\text { oxide })-E(\text { metal } / \text { oxide })) / A
$$

where $\mathrm{E}$ (metal/oxide) is the total energy of the relaxed $\mathrm{Cu}_{2} \mathrm{O}(111) \| \mathrm{Cu}(111)$ system. $\mathrm{E}$ (oxide) and $\mathrm{E}\left(\right.$ metal) are the total energies of the unrelaxed $\mathrm{Cu}_{2} \mathrm{O}(111)$ and $\mathrm{Cu}(111)$ parts, respectively, as calculated after separation and $\mathrm{A}$ is the area of the slab.

The adsorption energy of the water molecule was calculated as:

$$
E_{a d s}=\left[E\left(\operatorname{slab} / \mathrm{H}_{2} \mathrm{O}\right)-E(\operatorname{slab})-n E\left(\mathrm{H}_{2} \mathrm{O}\right)\right] / n
$$

where $\mathrm{E}\left(\mathrm{slab} / \mathrm{H}_{2} \mathrm{O}\right)$ is the total energy of the system with the water adsorbed on the slab surface. $\mathrm{E}(\mathrm{slab})$ and $\mathrm{E}\left(\mathrm{H}_{2} \mathrm{O}\right)$ are the energies of the clean relaxed slab and of one free water molecule optimized in vacuum, respectively, and $\mathrm{n}$ is the number of the water molecules adsorbed on the surface.

The adsorption energy of the radical $\mathrm{OH}^{\circ}$ was calculated as:

$$
E_{a d s}=\left[E(\operatorname{slab} / O H)-E(\operatorname{slab})-n E\left(O H^{\circ}\right)\right] / n
$$


where $\mathrm{E}(\mathrm{slab} / \mathrm{OH})$ is the total energy of the system with the $\mathrm{OH}^{\circ}$ groups adsorbed on the slab surface. $\mathrm{E}\left(\mathrm{OH}^{\circ}\right)$ is the energy of one free radical $\mathrm{OH}^{\circ}$ optimized in vacuum and $\mathrm{n}$ is the number of $\mathrm{OH}$ adsorbed on the surface.

In order to compare the stabilities at low and full (i.e. saturation) coverage of the adsorption of $\mathrm{H}_{2} \mathrm{O}$ and $\mathrm{OH}^{\circ}$, we normalized the adsorption energy per unit area as follows:

$$
\varepsilon_{\text {norm }}=E_{\text {ads }} \times \theta
$$

where $\mathrm{E}_{a d s}$ is the adsorption energy per molecule and $\theta=\frac{n}{A}$ the coverage, defined as the number of adsorbed molecules (n) per area (A) of the slab.

\section{Electronic and charge analysis}

The charge density difference analysis was plotted as:

$$
\Delta \rho(r)=\rho(r)_{s l a b / m o l}-\left(\rho(r)_{s l a b}+\rho(r)_{m o l}\right)
$$

where $\rho(r)_{s l a b / m o l}$ is the charge density distribution on the system, and $\rho(r)_{\text {slab }}$ and $\rho(r)_{m o l}$ are the charge density distributions on the isolated substrate and molecule at the geometry after adsorption, respectively.

The net charge variation was determined on each atom as:

$$
\Delta Q(x)=Q_{a d s}(x)-Q_{v a c}(x)
$$

where the $Q_{a d s}(x)$ and $Q_{v a c}(x)$ are the net charge on each atom (Bader population analysis $)^{53}$ of the molecule and the slab before and after adsorption, respectively. 
The work function change induced by the formation of the oxide on the metallic surface was calculated by:

$$
\Delta \phi=\phi^{\prime}-\phi
$$

where $\phi^{\prime}$ and $\phi$ are the work functions for the surface covered by the oxide and the bare metallic surface, respectively. The work function was calculated by the difference between the Fermi energy $\left(\mathrm{E}_{F}\right)$ of the system and the average electrostatic potential energy $\left(\mathrm{V}_{\infty}\right)$ in the middle of the vacuum region: $\phi=V_{\infty}-E_{F}$. The calculations were done with a dipole correction in the $\mathrm{z}$ direction and the total local potential (vasp LOCPOT) contains only the electrostatic contributions (ionic and Hartree).

\section{Results \& Discussion}

\section{Construction and geometrical properties of the $\mathrm{Cu}(111) \| \mathrm{Cu}_{2} \mathrm{O}(111)$ model}

In preliminary calculations, we characterized the bulk properties of $\mathrm{Cu}$-metal and $\mathrm{Cu}_{2} \mathrm{O}$-oxide as a first step to build the $\mathrm{Cu}(111) \| \mathrm{Cu}_{2} \mathrm{O}(111)$ structure. The lattice parameters obtained by PBE,${ }^{45,46}$ corrected by the semi empirical methods (DFT-D2 and DFT-D3) proposed by Grimme ${ }^{54,55}$ and non local functionals vdw-DF ${ }^{48}$ are summarized in Table 1 . We selected the optB86b functional optimized by Klimes et al, ${ }^{49,50}$ known for its ability to describe structural properties of solids. ${ }^{56}$ We found that it allows a good compromise of the lattice parameters of bulk $\mathrm{Cu}$-metal and $\mathrm{Cu}_{2} \mathrm{O}$-oxide with equilibrium lattice parameters of 3.599 $(-0.30 \%)$ and $4.272 \AA(+0.05 \%)$, respectively, which are in good agreement with experimental values of $3.61^{57}$ and $4.27 \AA .{ }^{58}$ The bulk was then cleaved to generate the surface structure.

The model used in the present calculations is derived from experimental data. ${ }^{1,11,17,59}$ 
Table 1: Lattice parameter and lattice mismatch of copper and cuprite bulk structures calculated with PBE functional and different correction schemes of van der Waals forces.

\begin{tabular}{c|l|l|l|l|l|}
\hline & \multicolumn{3}{|c}{$\mathrm{Cu}$ metal } & $\mathrm{Cu}_{2} \mathrm{O}$ oxide \\
\hline & $\mathrm{a}(\AA)$ & dev $(\%)$ & $\mathrm{a}(\AA)$ & $\mathrm{dev}(\%)$ & mismatch $(\%)$ \\
\hline PBE & 3.637 & +0.74 & 4.311 & +0.96 & 18.56 \\
DFT-D2 & 3.573 & -1.01 & 4.318 & +1.12 & 20.84 \\
DFT-D3 & 3.569 & -1.11 & 4.264 & -0.15 & 19.43 \\
vdw-DF2 & 3.746 & +3.78 & 4.421 & +3.55 & 18.02 \\
OptPBE-vdW & 3.648 & +1.06 & 4.327 & +1.35 & 18.62 \\
OptB88-vdW & 3.628 & +0.52 & 4.298 & +0.66 & 18.45 \\
OptB86b-vdW & 3.599 & -0.30 & 4.272 & +0.05 & 18.70 \\
\hline Exp. & \multicolumn{3}{|c}{$3.61^{57} 4.27^{58}$} & 18.28
\end{tabular}

It has been shown that in the $\mathrm{Cu}(\mathrm{II})$ potential range, the $\mathrm{Cu}(111)$ metal substrate is fully covered by a well crystallized $\mathrm{Cu}_{2} \mathrm{O}(111)$ oxide film in parallel epitaxy, ${ }^{1,5}$ which thickness is of 0.5 and 7 equivalent monolayers (ML) of $\mathrm{Cu}_{2} \mathrm{O}(111)$ after growth at -0.25 and $-0.2 \mathrm{~V} / \mathrm{SHE}$, respectively. Analysis of the observed structures showed a fit between oxide and substrate lattices over a coincidence length of $1.787 \mathrm{~nm}$ with a tilt angle of $5^{\circ}$ assigned to epitaxial stress. This fit implies a contraction of $1 \%$ of the oxide lattice or an expansion of $1 \%$ of the substrate lattice with respect to the bulk values.

We thus built a supercell containing a $(7 \times 7)$ supercell of $\mathrm{Cu}(111)$ matching a $(6 \times 6)$ supercell of $\mathrm{Cu}_{2} \mathrm{O}(111)$ stoichiometric oxide, and having the lateral dimensions of $1.781 \mathrm{~nm}$ in both $\mathrm{x}$ and $\mathrm{y}$ directions as calculated with optB86b functional. No tilt angle between the oxide layers and the metal was introduced. This constructed fit leads to the contraction of $1.7 \%$ of the oxide lattice relative to the bulk value, while the experimental value is 1\%. It also leads to a higher mismatch $(18.70 \%)$ than the experimental one $(18.28 \%)$. We varied the oxide thickness by covering the $\mathrm{Cu}(111)$ metal by two to six stoichiometric $\mathrm{Cu}_{2} \mathrm{O}(111)$ layers, corresponding to thicknesses ranging from 5.89 to $16.24 \AA$, as shown in Figure 1. The unrelaxed bare $\mathrm{Cu}_{2} \mathrm{O}(111)$ surface shown in Figure 2 exhibits two distinct copper sites corresponding to coordinatively saturated (csa) and coordinatively unsaturated (cus) $\mathrm{Cu}$ atoms, labeled as $\mathrm{Cu}_{c s a}$ and $\mathrm{Cu}_{c u s}$, respectively. It contains also two distinct oxygen sites corresponding to saturated and unsaturated oxygen atoms, labeled $\left(\mathrm{O}_{d n}\right)$ and $\left(\mathrm{O}_{u p}\right)$, 
respectively, where the subscripts indicate that they are located below ( $\mathrm{dn}$ ) and above (up) the surface $\mathrm{Cu}$ layer.

\section{Interface description}

In order to understand the interaction of $\mathrm{Cu}_{2} \mathrm{O}$ with the $\mathrm{Cu}$ metal, we analyzed the interfacial cohesion energy as calculated by rigidly cleaving the relaxed interface structure to produce two free surfaces and not allowing these two free surfaces to relax (Eq.1). Figure 3 shows the variation of this interfacial cohesion energy with increasing thickness of the oxide.

The cohesion energy is positive in the range between 2.09 and $2.21 \mathrm{~J} / \mathrm{m}^{2}$, indicating the stable formation of the interface between the stoichiometric $\mathrm{Cu}_{2} \mathrm{O}(111)$ oxide and the $\mathrm{Cu}(111)$ metal. The cohesion energy shows a slight decrease (about 5\%) for a 3-fold increase of the oxide thickness (from 2 to 6 monolayers). The $\mathrm{Cu}_{2} \mathrm{O}(111)$ oxide binds to the $\mathrm{Cu}(111)$ substrate surface through the bonding of the unsaturated oxygen atoms to the copper metal atoms. The oxygen atoms move laterally and are located on top, bridge and hollow sites on $\mathrm{Cu}(111)$ metal surface as illustrated in Figure 4. This result contrasts with that of Soon et $a l,{ }^{28}$ who found that the bridge site is energetically less favorable as compared to the fcc-hollow site for $\mathrm{O}$ adsorbed on $\mathrm{Cu}(111)$. The $\mathrm{Cu}-\mathrm{O}$ distances at the interface between copper metal and oxygen of the oxide is between 1.97 and $2.08 \AA$ on the top site, in the range between 2.06 and $2.40 \AA$ on the bridge site and between 2.17 an $2.35 \AA$ on the hollow site.

\section{Surface description}

It is known that the $\mathrm{Cu}_{2} \mathrm{O}(111)$ surface reconstructs after cleavage of the bulk structure. ${ }^{18,20,60,61}$ There are three symmetry equivalent directions along which $\mathrm{Cu}_{\text {cus }}$ ions may relax, with slightly different relaxation energies. ${ }^{60}$ For $\mathrm{Cu}(111) \| \mathrm{Cu}_{2} \mathrm{O}(111)$, we found the same tendency, the reconstructed $\mathrm{Cu}_{2} \mathrm{O}(111)$ surface being more stable by about $4 \mathrm{meV} / \AA^{2}$ than the high symmetry unreconstructed $\mathrm{Cu}_{2} \mathrm{O}(111)$ surface. The high symmetry around the 
unsaturated copper atoms is broken and the $\mathrm{Cu}_{\text {cus }}$ atoms relax laterally toward an adjacent saturated $\mathrm{Cu}_{c s a}$ atom, as shown in Figure $1 \mathrm{f}$ for non supported $\mathrm{Cu}_{2} \mathrm{O}(111)$ model. However, for $\mathrm{Cu}(111) \| \mathrm{Cu}_{2} \mathrm{O}(111)$ model the $\mathrm{Cu}_{\text {cus }}$ ions relax toward $\mathrm{Cu}_{\text {csa }}$ ions without any preferential direction, except for the 6-layer thick oxide.

Table 2: Comparison of distances and bond lengths $(\AA)$ at the oxide surface before and after relaxation, for non supported $\mathrm{Cu}_{2} \mathrm{O}(111)$ and supported $\mathrm{Cu}(111) \| \mathrm{Cu}_{2} \mathrm{O}(111)$ with oxide thickness ranging from 2 to 6 monolayers (ML). Distances and bond lengths are illustrated in Figure 2. $\mathrm{Cu}_{c u s}-\mathrm{Cu}_{c s a}^{1}$ and $\mathrm{Cu}_{c u s}-\mathrm{Cu}_{c s a}^{2}$ correspond to the contraction and elongation $\mathrm{Cu}_{c u s}-\mathrm{Cu}_{c s a}$ distances

\begin{tabular}{c|l|l|ll}
\hline Systems & $\mathrm{Cu}_{2} \mathrm{O}(111)^{\text {urlx }}$ & $\mathrm{Cu}_{2} \mathrm{O}(111)^{r l x}$ & $\mathrm{Cu}(111) \| \mathrm{Cu}_{2} \mathrm{O}(111)^{u l r x}$ & $\mathrm{Cu}(111) \| \mathrm{Cu}_{2} \mathrm{O}(111)^{r l x}$ \\
\hline $\mathrm{O}_{d n}-\mathrm{Cu}_{c s a}$ & 1.85 & 1.89 & 1.82 & $1.87 \pm 0.01$ \\
$\mathrm{O}_{u p}-\mathrm{Cu}_{C A S}$ & 1.85 & 1.85 & 1.82 & $1.82 \pm 0.01$ \\
$\mathrm{Cu}_{\text {cus }}-\mathrm{Cu}_{\text {csa }}^{1}$ & 3.02 & 2.45 & 2.97 & $2.36-2.45$ \\
$\mathrm{Cu}_{\text {cus }}-\mathrm{Cu}_{c s a}^{2}$ & 3.02 & 3.59 & 2.97 & $3.59-4.20$ \\
\hline
\end{tabular}

Table 2 shows the $\mathrm{O}-\mathrm{Cu}$ and $\mathrm{Cu}_{c s a}-\mathrm{Cu}_{c u s}$ distances (Figure 2) measured at the $\mathrm{Cu}_{2} \mathrm{O}(111)$ surface before and after relaxation for the non supported oxide and supported oxide. On the unrelaxed clean surface without lateral compression $\left(\mathrm{Cu}_{2} \mathrm{O}(111)^{u r l x}\right)$, the $\mathrm{O}_{u p^{-}} \mathrm{Cu}_{c s a}$ and $\mathrm{O}_{d n^{-}}$ $\mathrm{Cu}_{\text {csa }}$ distances are $1.85 \AA$ and the $\mathrm{Cu}_{\text {csa }}-\mathrm{Cu}_{\text {cus }}$ distance is $3.02 \AA$, while they are shorter by 0.03 and $0.05 \AA$ respectively, with lateral compression $\left(\mathrm{Cu}(111) \| \mathrm{Cu}_{2} \mathrm{O}(111)^{\text {urlx }}\right)$. For the supported oxide after relaxation and independently of the oxide thickness, the $\mathrm{O}_{d n^{-}}$ $\mathrm{Cu}_{c s a}$ distance is longer $(1.87 \pm 0.01 \AA)$ and the $\mathrm{O}_{u p}-\mathrm{Cu}_{c s a}$ distance is shorter $(1.82 \pm 0.01)$ compared to the ideal oxide surface $\left(\mathrm{Cu}_{2} \mathrm{O}(111)^{\text {urlx }}\right)$. These results are in line with that of Soon et al. ${ }^{28}$ who reported a compression by $2.1 \%$ of $\mathrm{O}-\mathrm{Cu}$ distance compared to that in the ideal oxide surface structure, due to the strong lateral constraint imposed to the supported oxide by using a supercell of $4 \times 4$. Because the high-symmetry of $\mathrm{Cu}_{\text {cus }}$ is broken after relaxation, the $\mathrm{Cu}_{c s a}-\mathrm{Cu}_{c u s}$ distance is significantly changed. As mentioned previously, the $\mathrm{Cu}_{\text {cus }}$ atoms move toward the $\mathrm{Cu}_{\text {csa }}$ sites, without preferential direction, because it has six $\mathrm{Cu}_{c s a}$ neighboring sites, which leads to the elongation of some $\mathrm{Cu}_{c s a}-\mathrm{Cu}_{c u s}$ distances and contraction of others. According to the relaxation direction of the $\mathrm{Cu}_{\text {cus }}$ atoms and the oxide thicknesses, the shorter distance ranges between 2.36 and $2.45 \AA$, and longer distance ranges 
between 3.59 and $4.20 \AA$.

The relaxation of the surface was also attested by the surface interlayer distance variation, shown in Figure 5 and calculated by the following equation:

$$
\Delta d=\frac{d_{s}-d_{b u l k}}{d_{b u l k}} \times 100
$$

where $d_{s}$ is the distance between the surface and the subsurface layers and $d_{b u l k}$ is the equivalent distance in the $\mathrm{Cu}_{2} \mathrm{O}$ bulk oxide.

It is interesting to notice that the direction of relaxation is opposite for the supported and non supported $\mathrm{Cu}_{2} \mathrm{O}$ oxides. For the $\mathrm{Cu}_{2} \mathrm{O}(111) \| \mathrm{Cu}(111)$, the surface interlayer relaxation is inward, i.e. the distance between the two topmost layer decreases compared to that in the bulk $(2.47 \AA)$. In contrast, the surface interlayer relaxation is outward in the non supported $\mathrm{Cu}_{2} \mathrm{O}(111)$ oxide. The interlayer distance converges toward the bulk value and reaches $0.42 \%$ and $+3.67 \%$ for the supported $\mathrm{Cu}_{2} \mathrm{O}(111) \| \mathrm{Cu}(111)$ and non supported $\mathrm{Cu}_{2} \mathrm{O}(111)$ oxides, respectively, with the 6 monolayer model.

These results show an opposite relaxation deviation of the interlayer distance induced by the underlying copper metal, and a slight effect of the constraint imposed to the oxide on the distance between the $\mathrm{Cu}_{c u s}$ and $\mathrm{Cu}_{c s a}$ atoms.

\section{Electrons distribution}

We used Bader charge analysis to identify the electrons distribution in the metal-oxide system and the results are compared to experimental and theoretical literature data. The results are presented in Table 3. In the oxide, the results show that the electrons distribution is independent of the oxide thickness. We found the presence of oxidized copper atoms and oxygen anions in the inner layers (i.e. bulk) of the oxide, on the surface and at the interface. We also found the expected metallic character of the metal support. In the bulk oxide, the 
copper cations have a Bader charge in the range between +0.5 and +0.6 electron, while oxygen anions exhibit typical charge of about -1 electron. The Bader charge analysis of the electrons distribution in the oxide is in good agreement with other theoretical charge distributions ${ }^{62-64}$ and also in line with the results of a high-energy synchrotron experimental investigation. ${ }^{65}$ The surface and the interface of the oxide contain saturated $\left(\mathrm{Cu}_{c s a}\right)$ and unsaturated $\left(\mathrm{Cu}_{\text {cus }}\right)$ copper cations. The $\mathrm{Cu}_{\text {csa }}$ cations exhibit a charge like in $\mathrm{Cu}$ cations in the bulk oxide, whereas the $\mathrm{Cu}_{\text {cus }}$ exhibit a lower charge in the range between +0.30 and +0.37 electron on the surface and of +0.19 and +0.20 electron at the interface with the metal. In the metal, Bader charge analyses shows the absence of charge $\left(\mathrm{Cu}^{+0}\right)$ in the bulk ( $\Delta \mathrm{Q}< \pm 0.03$ electron) and two types of copper atoms at the interface. The copper atoms bear charges varying from +0.10 to +0.20 electrons when involved in the interaction with oxygen atoms of the oxide, whereas the other copper atoms remain of metallic character $(\Delta \mathrm{Q}$ $< \pm 0.03$ electrons). This evidences a local electron transfer for the copper atoms involved in the interaction with oxygen atoms at the metal-oxide interface. The low charge transfer observed agrees with the more covalent than ionic nature of $\mathrm{Cu}_{2} \mathrm{O} .{ }^{66}$ The covalent character of $\mathrm{Cu}_{2} \mathrm{O}$ might explain the strong cohesion energy calculated, as it has been proposed that increasing the oxide covalency increases the metal/oxide interface strength. ${ }^{67}$

Table 3: Bader charge analysis of the electrons distribution (electron) on the $\mathrm{Cu}(111) \| \mathrm{Cu}_{2} \mathrm{O}(111)$ model with oxide thickness ranging from 2 to 6 monolayers.

\begin{tabular}{|c|c|c|c|c|}
\hline & This work & Ref. $^{62-64}$ & Ref. $^{65}$ \\
\hline Cu-metal & $\begin{array}{l}\mathrm{Cu} \text {-inner } \\
\mathrm{Cu} \text {-metal/inter }{ }^{1} \\
\mathrm{Cu} \text {-metal/inter }{ }^{2}\end{array}$ & $\begin{array}{l}< \pm 0.03 \\
+0.10 \text { to }+0.20\end{array}$ & & \\
\hline Cu-oxide & $\begin{array}{l}\mathrm{Cu} \text {-inner } \\
\mathrm{Cu}_{c s a} / \text { surf } \\
\mathrm{Cu}_{c s a} / \text { inter } \\
\mathrm{Cu}_{c u s} / \text { surf } \\
\mathrm{Cu}_{\text {cus }} / \text { inter }\end{array}$ & $\begin{array}{l}+0.50 \text { to }+0.60 \\
+0.30 \text { to }+0.37 \\
+0.19 \text { to }+0.20\end{array}$ & +0.53 & +0.57 to +0.84 \\
\hline & $\mathrm{O}$ & -1.03 to -0.99 & -1.07 to -1.05 & -1.68 to -1.14 \\
\hline
\end{tabular}




\section{Work function change and electrons transfer}

Table 4: Work function ( $\phi$ in $\mathrm{eV}$ ) for the $\mathrm{Cu}(111)$ and $\mathrm{Cu}_{2} \mathrm{O}(111)$ surface and work function change with respect to the metal work function $(\Delta \phi$ in $\mathrm{eV})$ and electrons transfer $(\Delta Q$ in $\left.\mathrm{e} / \AA^{2}\right)$ as function of the oxide thickness for the $\mathrm{Cu}_{2} \mathrm{O}(111) \| \mathrm{Cu}(111)$ model.

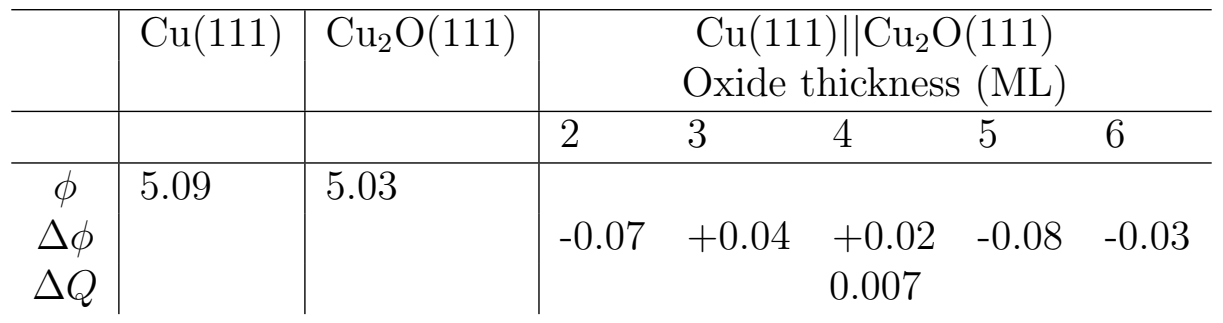

Table 4 shows the work function $(\phi)$ of the $\mathrm{Cu}(111)$ and $\mathrm{Cu}_{2} \mathrm{O}(111)$ surfaces and the work function change $(\Delta \phi)$ and electrons transfer $(\Delta Q)$ as a function of the oxide thickness for the $\mathrm{Cu}_{2} \mathrm{O}(111) \| \mathrm{Cu}(111)$ model. The formation of the $\mathrm{Cu}_{2} \mathrm{O}(111)$ stoichiometric oxide on the $\mathrm{Cu}(111)$ metal induces no significant change on the metal work function, which can be explained by the low charge transfer calculated after interaction and by the close work functions of the metal and the oxide. The work function change is related to the electrons transfer and, indeed, the Bader charge analysis reveals electrons transfer from the metal to the oxide of only $0.007 \mathrm{e} / \AA^{2}$. We calculated work functions of the $\mathrm{Cu}$ metal and the $\mathrm{Cu}_{2} \mathrm{O}$ oxide of 5.09 and $5.03 \mathrm{eV}$, respectively. These results contrast with those obtained for structures of oxygen adsorbed on the $\mathrm{Cu}$ surface, for which a work function change of 1.17 $\mathrm{eV}$ at $0.25 \mathrm{ML} \mathrm{O}$ coverage was calculated. ${ }^{28}$

\section{Reactivity toward water molecules and $\mathrm{OH}$ groups}

In order to model the experimental conditions of the copper surface in contact with an aqueous solution, we investigated the molecular and dissociative adsorption of water molecules and compared our results with literature data of water adsorbed on non supported $\mathrm{Cu}_{2} \mathrm{O}(111)$ oxide. We also hydroxylated the surface with $\mathrm{OH}$ groups placed on $\mathrm{Cu}_{\text {cus }}$. Two oxide thicknesses were considered, corresponding to 2 and 4 stoichiometric $\mathrm{Cu}_{2} \mathrm{O}(111)$ layers.

The results are presented in Figures 6 to 9 . Figures 6 and 7 show the snapshots of 
the starting and the most stable optimized configurations of molecular and dissociative adsorption of water molecules at low and high coverage, respectively. Figures 8 and 9 show snapshots of $\mathrm{OH}$ adsorption at low and high coverage, respectively. Table 5 summarizes the adsorption energies of molecular water and $\mathrm{OH}$ at low and high coverage compared to the literature data. More details on the water-surface and $\mathrm{OH}$-surface binding for two oxide thicknesses ( 2 and 4 stoichiometric $\mathrm{Cu}_{2} \mathrm{O}$ layers) are given by the charge density difference analysis $(\Delta \rho(r))$ calculated by Eq.5 and plotted in Figure 10, with isosurface of \pm 0.0004 $\mathrm{e} / \AA^{3}$.

Table 5: Adsorption energies $(\mathrm{eV} / \mathrm{mol})$ of water molecule and radical $\mathrm{OH}^{\circ}$ at low and full coverage as calculated with Eq.2 and Eq.3, respectively. Values in brackets correspond to the adsorption energy normalized per unit area $\left(\mathrm{J} / \mathrm{m}^{2}\right)$, calculated with Eq.4.

\begin{tabular}{c|l|l|c}
\hline $\begin{array}{c}\text { Oxide thickness } \\
\mathrm{Cu}_{2} \mathrm{O}(111) \text { monolayers }\end{array}$ & $\begin{array}{l}\text { coverage } \\
\left(\mathrm{mol} / \mathrm{nm}^{2}\right)\end{array}$ & $\begin{array}{l}\mathrm{H}_{2} \mathrm{O} \text { adsorption energy } \\
(\mathrm{eV} / \mathrm{mol})\end{array}$ & $\begin{array}{c}\mathrm{OH}^{\circ} \text { adsorption energy } \\
(\mathrm{eV} / \mathrm{mol})\end{array}$ \\
\hline 2 & 0.37 & $-1.26(-0.07)$ & $-3.74(-0.22) /-4.70(-0.27)$ \\
\hline 2 & 3.27 & $-1.10(-0.57)$ & $-3.71(-1.95)$ \\
\hline 4 & 3.27 & $-1.09(-0.57)$ & $-3.57(-1.87)$ \\
\hline \multirow{3}{*}{ non supported oxide } & $\frac{1}{4} \mathrm{ML}^{20}$ & -1.70 & \\
& $1 \mathrm{ML}^{20}$ & -1.01 & \\
& $1 \mathrm{ML}^{68}$ & -1.03 & \\
\hline
\end{tabular}

We found that independently of the oxide thickness, the water molecular adsorption (as shown in Figures 6 and 7) is favored over dissociative adsorption. The adsorption energy of the water molecule on $\mathrm{Cu}(111)$ covered by two $\mathrm{Cu}_{2} \mathrm{O}(111)$ layers is -1.26 and -1.10 $\mathrm{eV} /$ molecule at low and full coverage, respectively. On $\mathrm{Cu}(111)$ covered by four $\mathrm{Cu}_{2} \mathrm{O}(111)$ layers, the value is $-1.09 \mathrm{eV} /$ molecule at full coverage. The water molecules prefer to bind on top of unsaturated copper sites via the oxygen atom, with a bond length $\mathrm{Cu}$... O of $1.96 \pm 0.01$ $\AA$. The $\mathrm{Cu}$...O bond is confirmed by the charge density difference analysis in Figure 10, that shows the accumulation of electron charge (blue color) between the oxygen atom of the water molecules and the unsaturated copper atoms of the oxide surface. We also observed the formation of a H-O-H.... O hydrogen bond with an adjacent unsaturated oxygen with a H... distance of $1.69 \pm 0.01 \AA$ and $1.74 \pm 0.04 \AA$, on the two and four $\mathrm{Cu}_{2} \mathrm{O}$ layer thick 
models, respectively. The orientation of the hydrogen atom of the water molecule toward the unsaturated oxygen atom of the oxide surface and also the deficit and accumulation of electrons charge on the hydrogen (positive charge) and the unsaturated oxygen (negative charge) atoms (Figure 10), respectively, are typical features of H-bonding. Note that even when starting the calculations in the dissociative adsorption mode (Figure 7), we observed the reformation of intact water molecules at the end of the optimization process, which confirms preferential molecular adsorption of water on $\mathrm{Cu}(111) \| \mathrm{Cu}_{2} \mathrm{O}(111)$ surface. The water molecules were again adsorbed on unsaturated copper sites with the formation of H-bond. However at full coverage, one water molecules remains in the dissociative adsorption mode, with the $\mathrm{OH}$ group adsorbed atop on unsaturated copper and the $\mathrm{H}$ atom bounded to an unsaturated oxygen atom (Figure 7). This configuration allows us to estimate the dissociative energy of water molecule on the substrate surface. We calculated the value of $0.17 \mathrm{eV}$.

It is now interesting to compare our results of $\mathrm{H}_{2} \mathrm{O}$ adsorption on the supported $\mathrm{Cu}(111) \| \mathrm{Cu}_{2} \mathrm{O}(111)$ oxide with literature data of $\mathrm{H}_{2} \mathrm{O}$ adsorption on non supported $\mathrm{Cu}_{2} \mathrm{O}(111)$ oxide. Our results of favored molecular over dissociative adsorption are in agreement with literature data on the non supported oxide surface, showing that the oxide acid-base reactivity does not depend on the oxide layer thickness neither on the presence of the underlying $\mathrm{Cu}$ metal. The adsorption at high coverage is favored over that at low coverage, the gain in the adsorption is $\varepsilon_{\text {norm }}=0.50 \mathrm{~J} / \mathrm{m}^{2}$ (Table 5). The adsorption energy is also in accordance with previous theoretical results. ${ }^{20,68}$ Independently of coverage, the water molecule prefers molecular adsorption like observed on $\mathrm{Cu}_{2} \mathrm{O}(111)$ surfaces built with periodic ${ }^{20,68,69}$ or cluster ${ }^{19}$ models and also on $\mathrm{Cu}_{2} \mathrm{O}(111)$ surface with $\mathrm{Cu}$-vacancy. ${ }^{68}$ In the latter case, the water molecule binds via $\mathrm{H}$-bonding to oxygen in the sub layer, in the $\mathrm{Cu}$-vacancy and with the oxygen atom of the molecule is tilted toward $\mathrm{Cu}_{c s a}$ site. However the dissociative adsorption mode of $\mathrm{H}_{2} \mathrm{O}$ molecule can be preferential if the $\mathrm{Cu}_{2} \mathrm{O}(111)$ surface contains O-vacancies ${ }^{20,69}$ and also on the polar surfaces like the $\mathrm{Cu}$-terminated, $\mathrm{Cu}$-rich and O-rich $\mathrm{Cu}_{2} \mathrm{O}(111)$ surfaces. ${ }^{64}$ We also analyzed the adsorption of $\mathrm{OH}$ groups particularly present in alkaline solutions. 
Figures 8 and 9 show the results obtained at low and high coverage, respectively. The interaction mechanism of the $\mathrm{OH}$ groups with the surface is different from that of the water molecules. It does not show the formation of H-bonding and can involve both saturated and unsaturated copper surface atoms.

At low coverage, two optimized configurations were analyzed, due to their difference in the interaction mechanism. The first configuration has an adsorption energy of $-3.74 \mathrm{eV}$, and corresponds to the adsorption of $\mathrm{OH}$ on top of an unsaturated copper atom with a bond length $\mathrm{Cu}$... OH of $1.78 \AA$ and without the formation of $\mathrm{H}$-bonding between the $\mathrm{OH}$ group and the unsaturated oxygen surface atoms. The adsorption of $\mathrm{OH}$ in this configuration does not affect the structural environment of the neighboring atoms as compared to the bare $\mathrm{Cu}_{2} \mathrm{O}(111)$ surface.

The second configuration presents an adsorption energy of $-4.69 \mathrm{eV}$ and is more stable by $-0.95 \mathrm{eV}$. The $\mathrm{OH}$ group binds in a bridge mode with bond lengths $\mathrm{Cu}_{\text {cus }} \ldots \mathrm{O}$ of $1.88 \AA$ and $\mathrm{Cu}_{c s a} \ldots$ O of $1.89 \AA$. There is no H-bonding like in the first described configuration but there is a change in the structural environment of the neighboring surface atoms: i) broken bonding of an adjacent saturated copper with an unsaturated oxygen with a $\mathrm{Cu}_{c s a}-\mathrm{O}_{u p}$ bond length increase from $1.83 \AA$ to $2.97 \AA$, the $\mathrm{Cu}_{c s a}$ atom relaxes to bind to the $\mathrm{OH}$ group with a bond length of $1.89 \AA$; ii) the neighbor $\mathrm{Cu}_{\text {cus }}$ atom becomes a $\mathrm{Cu}_{c s a}$ atom, it moves to bind with an unsaturated oxygen $(\mathrm{Cu}-\mathrm{O}$ distance changes from 2.9 to $1.88 \AA$ ) that looses a bond with a saturated copper atom.

At high coverage, all unsaturated copper atoms of the $\mathrm{Cu}_{2} \mathrm{O}$ surface are bounded to $\mathrm{OH}$ groups. After relaxation, we observed two types of $\mathrm{OH}$ bonding. $\frac{2}{9}$ of $\mathrm{OH}$ groups in the supercell are $\mu_{1}-\mathrm{OH}$ groups, i.e. with $\mathrm{OH}$ adsorbed on top of unsaturated copper atoms, with bond length of $1.78 \AA$. This adsorption mode corresponds to that found at low coverage for the less stable configuration. $\frac{7}{9}$ of the $\mathrm{OH}$ groups in the supercell are $\mu_{2}$-OH groups, i.e. with each $\mathrm{OH}$ bonded in bridge mode to two copper atoms. The $\mathrm{Cu}$... O bond lengths are $1.84 \AA$ and $2.12 \AA$ with unsaturated and adjacent saturated copper atoms, respectively. Both types 
of $\mathrm{OH}$ bonds show bond-making without bond-breaking. The reason is that all unsaturated copper atoms become saturated after bonding with $\mathrm{OH}$ groups. More details about the $\mathrm{Cu} . . \mathrm{O}$ bond formation are given by $\Delta \rho(r)$ analysis in Figure 10 that shows electrons charge accumulation on the oxygen of the $\mathrm{OH}$ groups and local redistribution of electrons charge on copper surface atoms. We calculate a low deficit of the electrons charge on the unsaturated copper and higher deficit of the electrons charge on the saturated copper atoms particularly for those bonded to the $\mu_{2}-\mathrm{OH}$ groups.

The adsorption energy is $-3.72 \mathrm{eV} /$ molecule. The adsorption energy per $\mathrm{OH}$ at full coverage is lower than at low coverage, however, when the adsorption energy is normalized to a unit area (Table 5), the full coverage is more favorable, because more OH groups are adsorbed per unit area. The results also show that the adsorption of $\mathrm{OH}$ groups is more stable than the intact water molecule (energy difference of $2.62 \mathrm{eV}$ ). The energetic trend suggests that surface saturation by $\mathrm{OH}$ groups of the $\mathrm{Cu}(111) \| \mathrm{Cu}_{2} \mathrm{O}(111)$ supported oxide is, in principal, favored in conditions where $\mathrm{OH}$ group adsorption can compete with water molecular adsorption, but that it would not likely happen by direct dissociation of water molecules.

\section{Conclusions}

In this paper, we presented a DFT-based construction and optimization of $\mathrm{Cu}_{2} \mathrm{O}(111)$ oxide supported in parallel epitaxy on the $\mathrm{Cu}(111)$ as model for metallic copper covered by an ultrathin $\mathrm{Cu}(\mathrm{II})$ oxide. Hydration and hydroxylation of the topmost surface of the supported $\mathrm{Cu}(111) \| \mathrm{Cu}_{2} \mathrm{O}(111)$ model was discussed. We provided results for structural, energetic and electronic properties of dry, hydrated and hydroxylated systems. The results were compared to equivalent data on non supported $\mathrm{Cu}_{2} \mathrm{O}(111)$ oxide.

We found the stable formation of stoichiometric $\mathrm{Cu}_{2} \mathrm{O}(111)$ oxide in parallel epitaxy on the $\mathrm{Cu}(111)$ metal. The interfacial cohesion energy decreases slightly with increasing oxide 
thickness. We showed that the surface relaxation is independent of the oxide thickness, and similar to that of the non supported $\mathrm{Cu}_{2} \mathrm{O}(111)$ oxide with slight effect on $\mathrm{Cu}_{\text {cus }}-\mathrm{Cu}_{\text {csa }}$ distance imposed by the lateral constraint in the supported oxide. The underlying copper metal was found to modify the relaxation changes in the deviation of the surface interlayer distance as compared to the non supported oxide, and converges to that of bulk oxide with increasing the $\mathrm{Cu}_{2} \mathrm{O}(111)$ thickness.

Bader charge analyses revealed the metallic and oxide character of the copper metal atoms at the metal and oxide planes forming the interface. The close values of the work function of the metal and the oxide combined to the weak electron exchange at the interface causes non significant variation of the metal work function, whatever the thickness of the supported oxide.

Independently of the oxide thickness, water molecules prefer molecular adsorption rather than dissociative adsorption. The adsorption at high coverage is favored over that at low coverage. The electronic analysis confirms that the water molecules bind covalently via $\mathrm{O}$ to $\mathrm{Cu}_{\text {cus }}$ atoms and form also $\mathrm{H}$-bonds with $\mathrm{O}_{\text {up }}$ surface atoms.

The hydroxylation of the surface shows two types of bonding for the adsorbed OH groups; $\mathrm{OH}-\mu_{1}$ and $\mathrm{OH}-\mu_{2}$, with predominance of $\mathrm{OH}-\mu_{2}$ mode. In $\mathrm{OH}-\mu_{1}$ mode, the $\mathrm{OH}$ group is chemisorbed via the $\mathrm{O}$ atom on top of a $\mathrm{Cu}_{\text {cus }}$ atom, whereas in the $\mathrm{OH}-\mu_{2}$ mode, the $\mathrm{OH}$ is chemisorbed via the $\mathrm{O}$ atom bridging the $\mathrm{Cu}_{c u s}$ and $\mathrm{Cu}_{c s a}$ atoms. The energetic trend suggests that the complete surface hydroxylation of the $\mathrm{Cu}(111) \| \mathrm{Cu}_{2} \mathrm{O}(111)$ supported oxide is favored in conditions where $\mathrm{OH}$ group adsorption can compete with water molecular adsorption.

\section{Acknowledgement}

This project has received funding from the European Research Council (ERC) under the European Union's Horizon 2020 research and innovation program (ERC Advanced Grant No. 
741123, Corrosion Initiation Mechanisms at the Nanometric and Atomic Scales : CIMNAS).

\section{References}

(1) Kunze, J.; Maurice, V.; Klein, L. H.; Strehlowa, H.-H.; Marcus, P. In Situ Scanning Tunneling Microscopy Study of the Anodic Oxidation of $\mathrm{Cu}(111)$ in $0.1 \mathrm{M} \mathrm{NaOH}$. J. Phys. Chem. B 2001, 105, 4263-4269.

(2) Poizot, P.; Laruelle, S.; Grugeon, S.; Dupont, L.; Tarascon, J. M. Nano-Sized Transition-Metal Oxides as Negative-Electrode Materials for Lithium-Ion Batteries. Nature 2000, 407, 496.

(3) Hara, M.; Kondo, T.; Komoda, M.; Ikeda, S.; Shinohara, K.; Tanaka, A.; Kondo, J.; Domen, K. $\mathrm{Cu}_{2} \mathrm{O}$ as a Photocatalyst for Overall Water Splitting Under Visible Light Irradiation. Chem. Commum. 1998, 357.

(4) Zhou, R.; Yu, T.; Jiang, X.; Chen, F.; Zheng, X.

(5) Marcus, P.; Maurice, V. Atomic Level Characterization in Corrosion Studies. Phil. Trans. R. Soc. 2017, A375, 20160414.

(6) Henderson, M. A. The Interaction of Water with Solid Surfaces: Fundamental Aspects Revisited. Surf. Sci. Rep. 2002, 46, 1-308.

(7) Thiel, P. A.; Madey, T. E. The Interaction of Water with Solid Surfaces: Fundamental Aspects. Surf. Sci. Rep. 1987, 7, 211-385.

(8) Gründer, Y.; Drünkler, A.; Golks, F.; Wijts, G.; Stettner, J.; Zegenhagen, J.; Magnussen, O. M. Structure and Electrocompression of Chloride Adlayers on $\mathrm{Cu}(111)$. Surf. Sci. 2011, 605, 1732-1737. 
(9) Gründer, Y.; Drünkler, A.; Golks, F.; Wijts, G.; Stettner, J.; Zegenhagen, J.; Magnussen, O. M. Cu(111) in Chloride Containing Acidic Electrolytes: Coadsorption of an Oxygenated Species. J. Electroanal. Chem. 2014, 712, 74-81.

(10) Baricuatro, J. H.; Ehlers, C. B.; Cummins, K. D.; Soriaga, M. P.; Stickney, J. L.; Kim, Y.-G. Structure and Composition of $\mathrm{Cu}(\mathrm{hkl})$ Surfaces Exposed to $\mathrm{O}_{2}$ and Emersed from Alkaline Solutions: Prelude to UHV-EC Studies of $\mathrm{CO}_{2}$ Reduction at Well-Defined Copper Catalysts. J. Electroanal. Chem. 2014, 716, 101-105.

(11) Maurice, V.; Strehlowa, H.-H.; Marcus, P. In Situ STM Study of the Initial Stages of Oxidation of $\mathrm{Cu}(111)$ in Aqueous Solution. Surf. Sci. 2000, 458, 185-194.

(12) Abrahami, S. T.; Chiter, F.; Klein, L. H.; Maurice, V.; Terryn, H.; Costa, D.; Marcus, P. In Situ EC-STM Study and DFT Modeling of the Adsorption of Glycerol on $\mathrm{Cu}(111)$ in NaOH Solution. J. Phys. Chem. C 2019, 123, 22228-22238.

(13) Lahti, M.; Chaudhuri, A.; Pussi, K.; Hesp, D.; McLeod, I. M.; Dhanak, V. R.; King, M. O.; Kadodwala, M.; MacLaren, D. A. The Structure Analysis of Cu(111)$\mathrm{Te}(\sqrt{3} \times \sqrt{3}) \mathrm{R}^{\circ} 0^{\circ}$ and $(2 \sqrt{3} \times 2 \sqrt{3}) \mathrm{R}^{\circ} 0^{\circ}$ Surface Phases by Quantitative LEED and DFT. Surf. Sci. 2014, 622, 35-43.

(14) Sander, U.; Strehblow, H.-H.; Dohrmann, J. K. In Situ Photoacoustic Spectroscopy of Thin Oxide Layers on Metal Electrodes. Copper in Alkaline Solution. J. Phys. Chem.

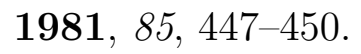

(15) Finšgar, M.; Peljhan, S.; Kokalj, A.; Kovacc, J.; Milošev, I. Determination of the $\mathrm{Cu}_{2} \mathrm{O}$ Thickness on BTAH-Inhibited Copper by Reconstruction of Auger Electron Spectra. J. Electrochem. Soc. 2010, 157, C295-C301.

(16) Strehblow, H.-H.; Titze, B. The Investigation of the Passive Behaviour of Copper in Weakly Acid and Alkaline Solutions and the Examination of the Passive Film by esca and ISS. Electrochim. Acta. 1979, 25, 839-850. 
(17) Kunze, J.; Maurice, V.; Klein, L. H.; Strehlowa, H.-H.; Marcus, P. In Situ STM Study of the Duplex Passive Films Formed on $\mathrm{Cu}(111)$ and $\mathrm{Cu}(001)$ in $0.1 \mathrm{M} \mathrm{NaOH}$. Corros. Sci. 2004, 46, 245-264.

(18) Kokalj, A.; Peljhan, S. Density Functional Theory Study of Adsorption of Benzotriazole on $\mathrm{Cu}_{2} \mathrm{O}$ Surfaces. J. Phys. Chem. C 2015, 119, 11625-11635.

(19) Casarin, M.; Maccato, C.; Vigato, N.; Vittadini, A. A Theoretical Study of the $\mathrm{H}_{2} \mathrm{O}$ and $\mathrm{H}_{2} \mathrm{~S}$ Chemisorption on $\mathrm{Cu}_{2} \mathrm{O}(111)$. Appl. Surf. Sci. 1999, 142, 164-168.

(20) Yu, X.; Zhang, X.; Wang, S.; Feng, G. A Computational Study on Water Adsorption on $\mathrm{Cu}_{2} \mathrm{O}(111)$ Surfaces: The Effects of Coverage and Oxygen Defect. Appl. Surf. Sci. 2015, 343, 33-40.

(21) Gharachorlou, A.; Detwiler, M. D.; Gu, X.-K.; Mayr, L.; Klötzer, B.; Greeley, J.; Reifenberger, R. G.; Delgass, W. N.; Ribeiro, F. H.; Zemlyanov, D. Y. Trimethylaluminum and Oxygen Atomic Layer Deposition on Hydroxyl-Free $\mathrm{Cu}(111)$. ACS Appl. Mater. Interfaces 2015, 7, 16428-16439.

(22) An, D. W.; Xu, F.; Stacchiola, D. D.; Liu, P. Potassium-Induced Effect on Structure and Chemical Activity of $\mathrm{CuxO} / \mathrm{Cu}(111)(\mathrm{x} \leq 2)$ Surface: A Combined Scanning Tunneling Microscopy and Density Functional Theory Study. ChemCatChem 2015, 7, 23.

(23) Therrien, A. J.; Zhang, R.; Lucci, F. R.; Marcinkowski, M. D.; Hensley, A.; McEwen, J.-S.; Sykes, E. C. H. Structurally Accurate Model for the "29"-Structure of CuxO/Cu(111): A DFT and STM Study. J. Phys. Chem. C 2016, 120, 10879-10886.

(24) Hensley, A. J. R.; Therrien, A. J.; Zhang, R.; Marcinkowski, M. D.; Lucci, F. R.; Sykes, E. C. H.; McEwen, J.-S. CO Adsorption on the "29" CuxO/Cu(111) Surface: An Integrated DFT, STM, and TPD Study. J. Phys. Chem. C 2016, 120, 25387-25394. 
(25) Park, J.-H.; Lee, J.-H.; Soon, A. Organics on Oxidic Metal Surfaces: a First-Principles DFT Study of PMDA and ODA Fragments on the Pristine and Mildly Oxidized Surfaces of $\mathrm{Cu}(111)$. Phys. Chem. Chem. Phys. 2016, 18, 21893.

(26) Jensen, F.; Besenbacher, F.; Lægsgaard, E.; Stensgaard, I. Surf. Sci. 1991, 1259.

(27) Yang, F.; Choi, Y.; Liu, P.; Hrbek, J.; Rodriguez, J. A. Autocatalytic Reduction of a $\mathrm{Cu}_{2} \mathrm{O} / \mathrm{Cu}(111)$ Surface by CO: STM, XPS, and DFT Studies. J. Phys. Chem. C 2010, $114,17042-17050$.

(28) Soon, A.; Todorova, M.; Delley, B.; Stampfl, C. Oxygen Adsorption and Stability of Surface Oxides on $\mathrm{Cu}(111)$ : A First-Principles Investigation. Phys. rev. B 2006, 73, 165424.

(29) xiang Yu, X.; Marks, L. D. Combining the Physics of Metal/Oxide Heterostructure, Interface Dipole, Band Bending, Crystallography, and Surface State to Understand Heterogeneity Contrast in Oxidation and Corrosion. Corrosion 2019, 75, 152-166.

(30) Möller, C.; Nilius, N. Water Adsorption on $\mathrm{Cu}_{2} \mathrm{O}(111)$ Surfaces: A Scanning Tunneling Microscopy Study. J. Phys. Chem. C 2017, 121, 20877-20881.

(31) Sträter, H.; Fedderwitz, H.; Groß, B.; Nilius, N. Growth and Surface Properties of Cuprous Oxide Films on Au(111). J. Phys. Chem. C 2015, 119, 5975-5981.

(32) Brandt, I. S.; Martins, C. A.; Zoldan, V. C.; Viegas, A. D. C.; da Silva, J. H. D.; Pasa, A. A. Structural and Optical Properties of $\mathrm{Cu}_{2} \mathrm{O}$ Crystalline Electrodeposited Films. Thin Solid Films 2014, 562, 144-151.

(33) Costa, D.; Ribeiro, T.; Mercuri, F.; Pacchioni, G.; Marcus, P. Atomistic Modeling of Corrosion Resistance: A First Principles Study of $\mathrm{O}_{2}$ Reduction on the $\mathrm{Al}(111)$ Surface Covered with a Thin Hydroxylated Alumina Film. Adv. Mater. Interfaces 2014, 1, 1300072. 
(34) Tan, Y. S.; Srinivasan, M.; Pehkonen, S. O.; Chooi, S. Y. M. Effects of Ring Substituents on the Protective Properties of Self-Assembled Benzenethiols on Copper. Corros. Sci. 2006, 48, 840-862.

(35) Wu, X.; Wiame, F.; Maurice, V.; Marcus, P. Adsorption and Thermal Stability of 2-Mercaptobenzothiazole Corrosion Inhibitor on Metallic and pre-Oxidized $\mathrm{Cu}(111)$ Model Surfaces. Appl. Surf. Sci. 2020, 508, 145132.

(36) Wu, X.; Wiame, F.; Maurice, V.; Marcus, P. 2-Mercaptobenzothiazole Corrosion Inhibitor Deposited at Ultra-Low Pressure on Model Copper Surfaces. Corros. Sci. 2020, $166,108464$.

(37) Wu, X.; Wiame, F.; Maurice, V.; Marcus, P. 2-Marcaptobenzimidazole Films Formed at Ultra-Low Pressure on Copper: Adsorption, Thermal Stability and Corrosion Inhibition Performance. Appl. Surf. Sci. 2020, 527, 146814.

(38) Chiter, F.; Costa, D.; Maurice, V.; Marcus, P. DFT Investigation of 2Mercaptobenzothiazole Adsorption on Model Oxidized Copper Surfaces and Relationship with Corrosion Inhibition. submitted to Appl. Surf. Sci. 2020,

(39) Sun, G.; Kürti, J.; Rajczy, P.; Kertesz, M.; Hafner, J.; Kresse, G. Performance of the Vienna ab Initio Simulation Package (VASP) in Chemical Applications. J. Mol. Struct. THEOCHEM 2003, 624, 37-45.

(40) Kresse, G.; Hafner, J. Phys. rev. B 1993, 47, 558.

(41) Kresse, G.; Furthmüller, J. Efficiency of ab-Initio Total Energy Calculations for Metals and Semiconductors Using a Plane-Wave Basis Set. Comput. Mater. Sci 1996, 6, 15-50.

(42) Kresse, G.; Furthmüller, J. Efficient Iterative Schemes for ab Initio Total-Energy Calculations Using a Plane-Wave Basis Set. Phys. Rev. B 1996, 54, 11169-11186. 
(43) Kresse, G.; Joubert, D. From Ultrasoft Pseudopotentials to the Projector AugmentedWave Method. Phys. Rev. B 1999, 59, 1758-1775.

(44) Blöchl, P. E. Projector augmented-wave method. Phys. Rev. B 1994, 50.

(45) Perdew, J. P.; Chevary, J. A.; Vosko, S. H.; Jackson, K. A.; Pederson, M. R.; Singh, D. J.; Fiolhais, C. Atoms , Molecules , Solids , and Surfaces: Applications of the Generalized Gradient Approximation for Exchange and Correlation. Phys. Rev. $B 1992,46$.

(46) Perdew, J. P.; Burke, K.; Ernzerhof, M. Generalized Gradient Approximation Made Simple. Phys. Rev. Lett. 1996, 77.

(47) Methfessel, M.; Paxton, A. T. High-Precision Sampling for Brillouin-Zone Integration in Metals. Phys. Rev. B 1989, 40 .

(48) Dion, M.; Rydberg, H.; Schröder, E.; Langreth, D. C.; Lundqvist, B. I. Van der Waals Density Functional for General Geometries. Phys. Rev. Lett. 2004, 92, 246401.

(49) Klimê̂, J.; Bowler, D. R.; Michaelides, A. Chemical Accuracy for the Van der Waals Density Functional. J. Phys.: Condens. 2010, 22, 022201.

(50) Klimeš, J.; Bowler, D. R.; Michaelides, A. Van der Waals Density Functionals Applied to Solids. Phys. rev. B 2011, 83, 195131.

(51) Klimeš, J.; Michaelides, A. Perspective: Advances and Challenges in Treating Van der Waals Dispersion Forces in Density Functional Theory. J. Chem. Phys.s 2012, 137, 120901.

(52) Monkhorst, H. J.; Pack, J. D. Special Points for Brillonin-Zone Integrations. Phys. Rev. $B$ 1976, 13.

(53) Tang, W.; Sanville, E.; Henkelman, G. A Grid-Based Bader Analysis Algorithm without Lattice Bias. J. Phys.: Condens. Matter 2009, 21, 084204. 
(54) Grimme, S. Semiempirical GGA-Type Density Functional Constructed with a LongRange Dispersion Correction. J. Comput. Chem. 2006, 27.

(55) Grimme, S.; Antony, J.; Ehrlich, S.; Krieg, H. A Consistent and Accurat ab Initio Parametrization of Density Functional Dispersion Correction (DFT-D) for the 94 Elements H-Pu. J. Chem. Phys. 2010, 132, 154104-154119.

(56) Chiter, F.; Nguyen, V. B.; Tarrat, N.; Benoit, M.; Tang, H.; Lacaze-Dufaure, C. Effect of Van der Waals Corrections on DFT-Computed Metallic Surface Properties. Mater. Res. Express 2016, 3, 046501.

(57) Kittel, C. Introduction to Solid State Physics, 7th ed.; Wiley Sons, New York, 1996.

(58) Werner, A.; Hochheimer, H. D. High-pressure X-ray Study of $\mathrm{Cu}_{2} 0$ and Ag20. Phys. rev. B 1982, 25, 5929 .

(59) Kunze, J.; Maurice, V.; Klein, L. H.; Strehlowa, H.-H.; Marcus, P. In Situ STM Study of the Effect of Chlorides on the Initial Stages of Anodic Oxidation of $\mathrm{Cu}(111)$ in Alkaline Solutions. Electrochim. Acta. 2003, 48, 1157-1167.

(60) Gustincic, D.; Kokalj, A. DFT Study of Azole Corrosion Inhibitors on $\mathrm{Cu}_{2} \mathrm{O}$ Model of Oxidized Copper Surfaces: I. Molecule-Surface and Cl-Surface Bonding. Metals 2018, 8,310 .

(61) Yu, X.; Zhang, X.; Wang, H.; Wang, Z.; Feng, G. High-Coverage $\mathrm{H}_{2}$ Adsorption on the Reconstructed $\mathrm{Cu}_{2} \mathrm{O}(111)$ Surface. J. Phys. Chem. C 2017, 121, 22081-22091.

(62) Laskowski, R.; Blaha, P.; Schwarz, K. Charge Distribution and Chemical Bonding in $\mathrm{Cu}_{2}$ O. Phys. rev. B 2003, 67, 075102.

(63) Islam, M. M.; Diawara, B.; Maurice, V.; Marcus, P. Bulk and Surface Properties of $\mathrm{Cu}_{2} \mathrm{O}$ : A First-Principles Investigation. J. Mol. Struc-THEOCHEM 2009, 903, 41-48. 
(64) Islam, M. M.; Diawara, B.; Maurice, V.; Marcus, P. First Principles Investigation on the Stabilization Mechanisms of the Polar Copper Terminated $\mathrm{Cu}_{2} \mathrm{O}(111)$ Surface. Surf. Sci. 2009, 603, 2087-2095.

(65) Lippmann, T.; Schneider, J. R. Topological Analyses of Cuprite, $\mathrm{Cu}_{2} \mathrm{O}$, Using HighEnergy Synchrotron-Radiation Data. Acta Cryst. 2000, A56, 575-584.

(66) Evarestov, R. A.; Tupitsin, I. I.; Veryazov, V. A.

(67) Jarvis, E. A. A.; Carter, E. A. Exploiting Covalency to Enhance Metal-Oxide and Oxide--Oxide Adhesion at Heterogeneous Interfaces.

(68) Riplinger, C.; Carter, E. A. Cooperative Effects in Water Binding to Cuprous Oxide Surfaces. J. Phys. Chem. C 2015, 119, 9311-9323.

(69) Zhang, R.; Li, J.; Wang, B.; Ling, L. Fundamental Studies about the Interaction of Water with Perfect, Oxygen-Vacancy and pre-Covered Oxygen $\mathrm{Cu}_{2} \mathrm{O}(111)$ Surfaces: Thermochemistry, Barrier, Product. Appl. Surf. Sci. 2013, 279, 260-271. 


\section{Graphical TOC Entry}

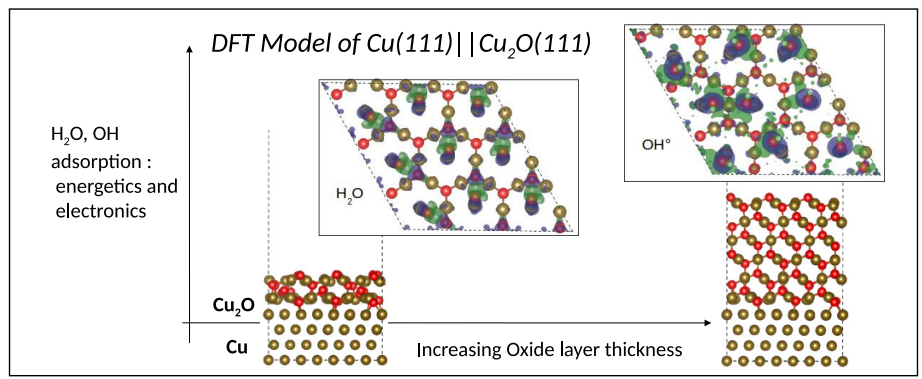




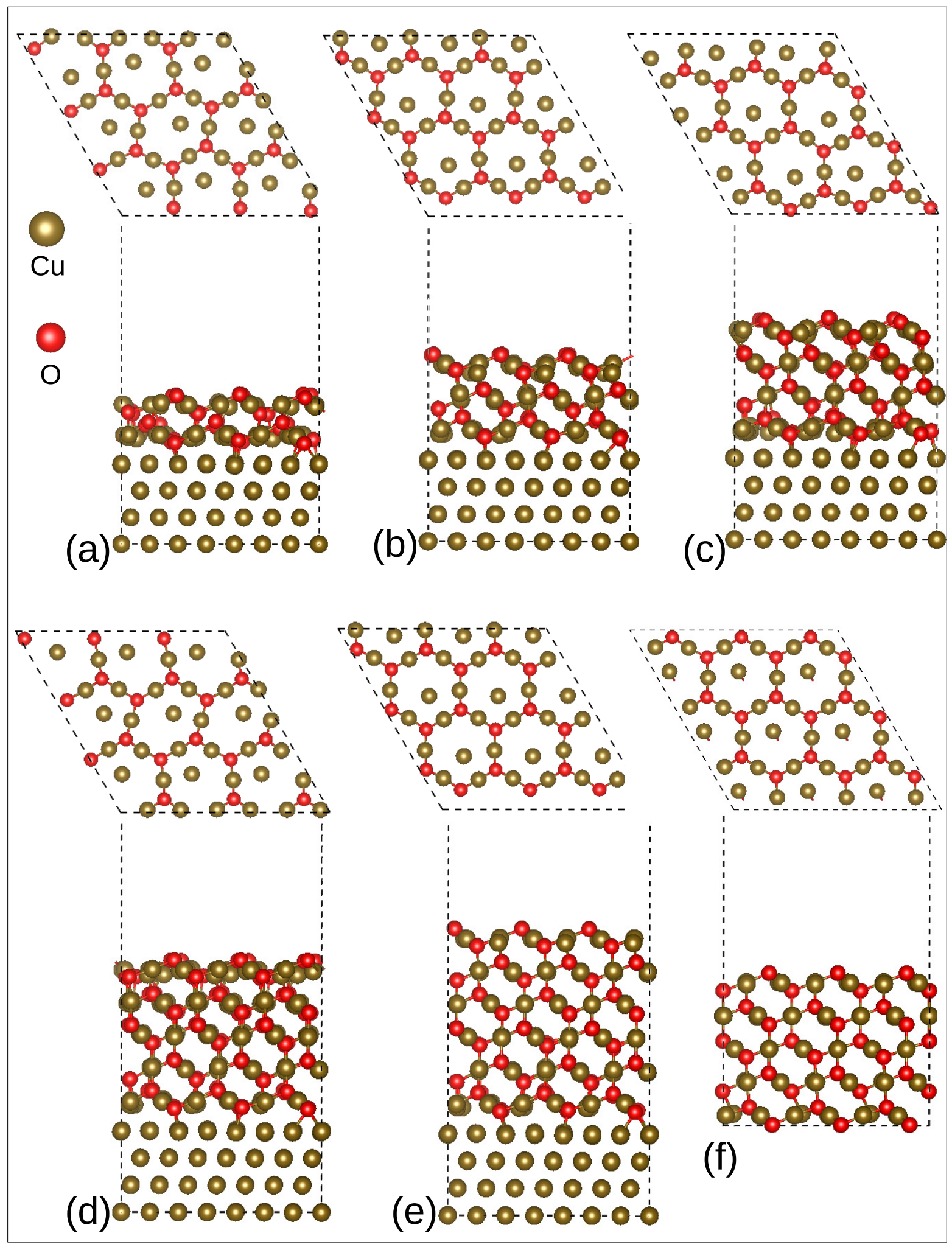

Figure 1: Snapshots (top and side views) of $\mathrm{Cu}(111)$ covered by stoichiometric $\mathrm{Cu}_{2} \mathrm{O}(111)$ in parallel epitaxy with thickness from two (a) to six (e) layers. (f) is the non supported 5-layer thick $\mathrm{Cu}_{2} \mathrm{O}(111)$ oxide. 


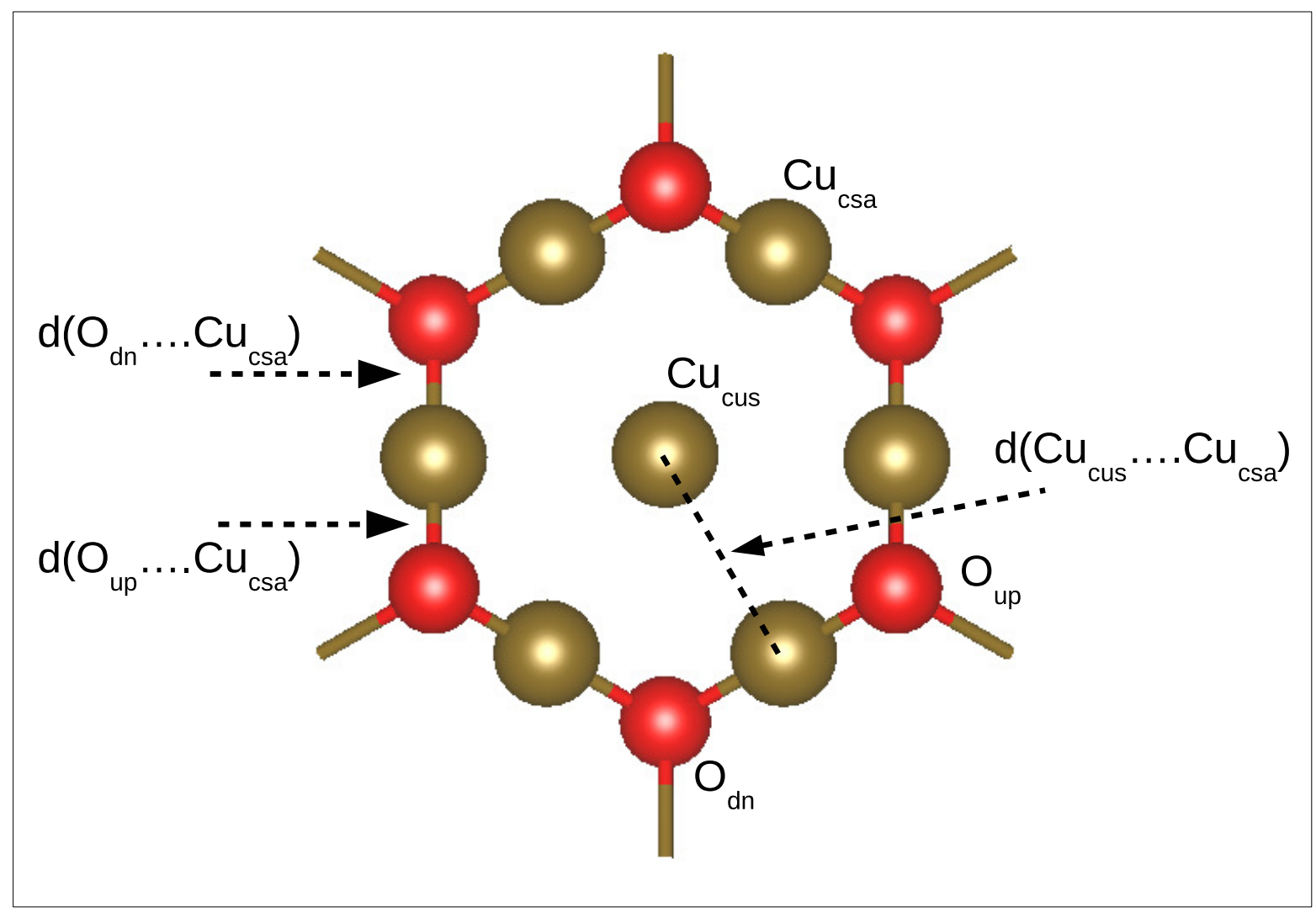

Figure 2: Surface sites, bond lengths and distances of $\mathrm{Cu}_{2} \mathrm{O}(111) \cdot \mathrm{Cu}_{\text {cus }}$ and $\mathrm{Cu}_{\text {csa }}$ correspond to unsaturated and saturated copper surface sites, respectively. $\mathrm{O}_{u p}$ and $\mathrm{O}_{d n}$ correspond to unsaturated and saturated oxygen surface sites, respectively. $\mathrm{d}\left(\mathrm{O}_{d n} \ldots \mathrm{Cu}_{c s a}\right)$ and $\mathrm{d}\left(\mathrm{O}_{u p} \ldots \mathrm{Cu}_{c s a}\right)$ are the bond length of $\mathrm{O}_{d n}$ and $\mathrm{O}_{u p}$ to $\mathrm{Cu}_{c s a}$ atoms, respectively. $\mathrm{d}\left(\mathrm{Cu}_{\text {cus }} \ldots \mathrm{Cu}_{\text {csa }}\right)$ is the distance between $\mathrm{Cu}_{\text {cus }}$ and $\mathrm{Cu}_{\text {csa }}$ atoms. 


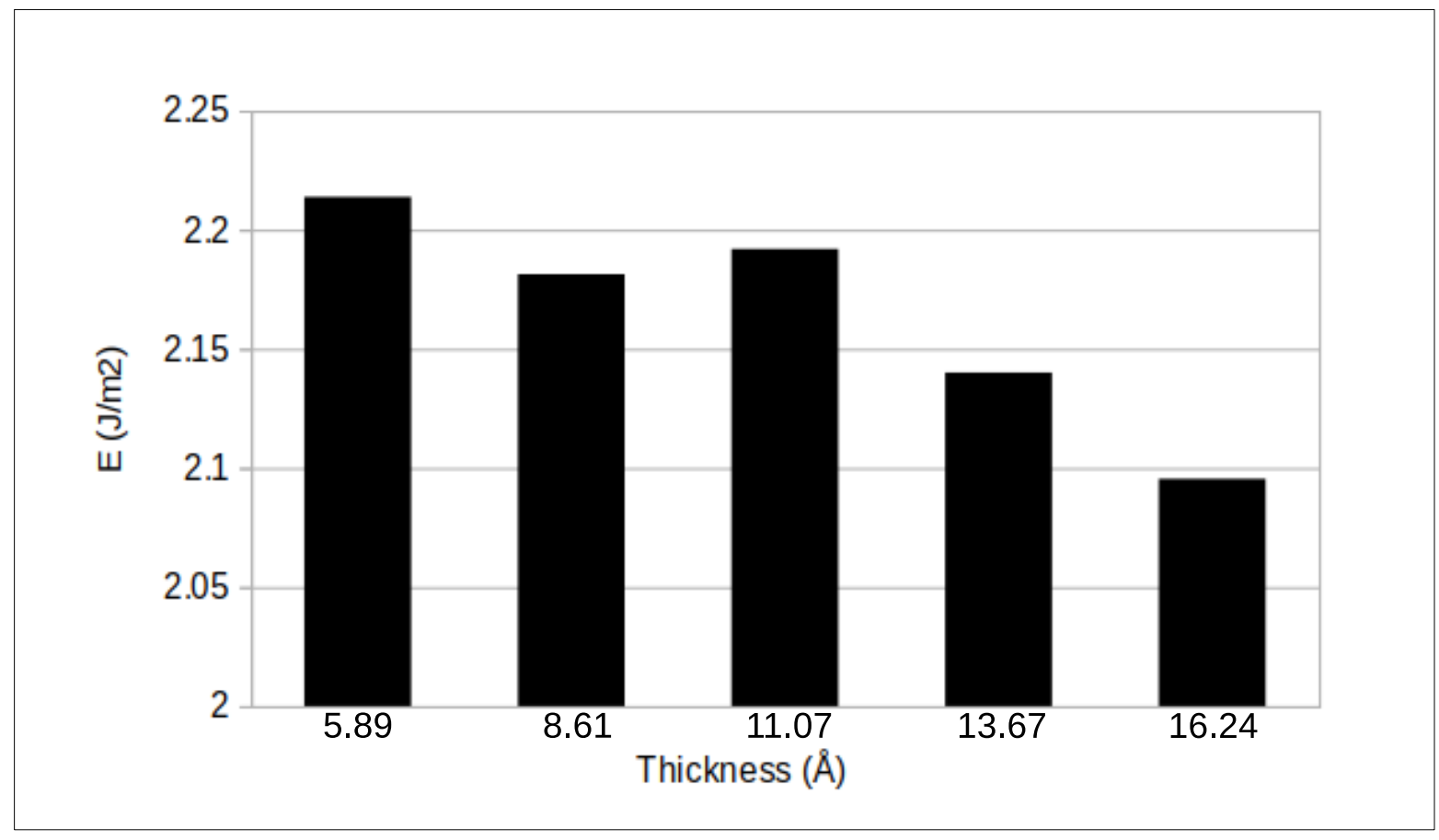

Figure 3: Cohesion energy of $\mathrm{Cu}(111) \| \mathrm{Cu}_{2} \mathrm{O}(111)$ interface as calculated with Eq. 1 as a function of the oxide thickness. 


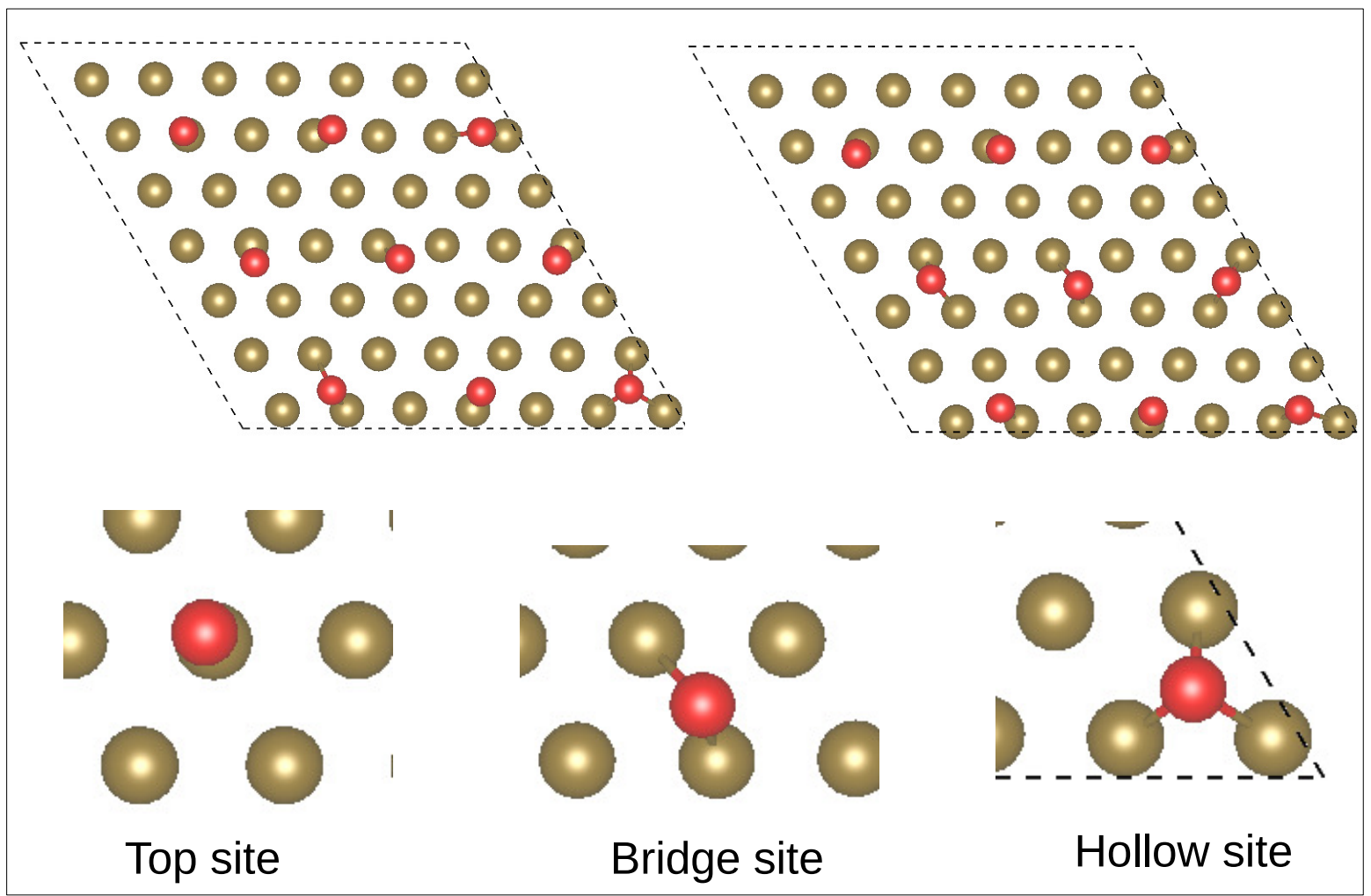

Figure 4: Details of the $\mathrm{O}$ to metallic $\mathrm{Cu}$ bonding at the oxide-metal interface in $\mathrm{Cu}(111) \| \mathrm{Cu}_{2} \mathrm{O}(111)$ model. For visualization we kept only the last metallic layer of copper metal and first oxygen layer of the oxide at the interface. 


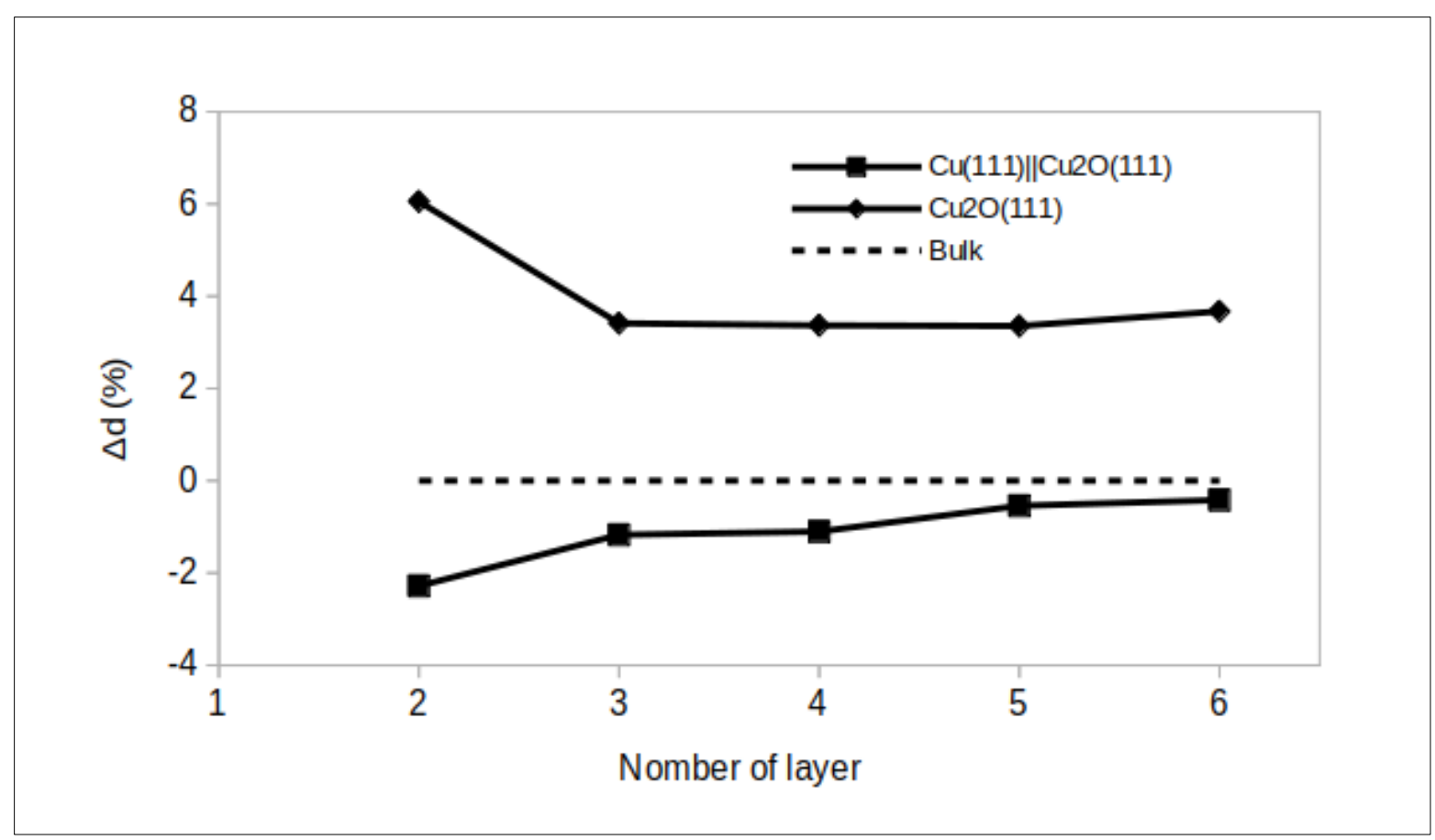

Figure 5: Deviation of the calculated surface interlayer distance with respect to bulk for the supported $\mathrm{Cu}(111) \| \mathrm{Cu}_{2} \mathrm{O}(111)$ and non supported $\mathrm{Cu}_{2} \mathrm{O}(111)$ oxides.

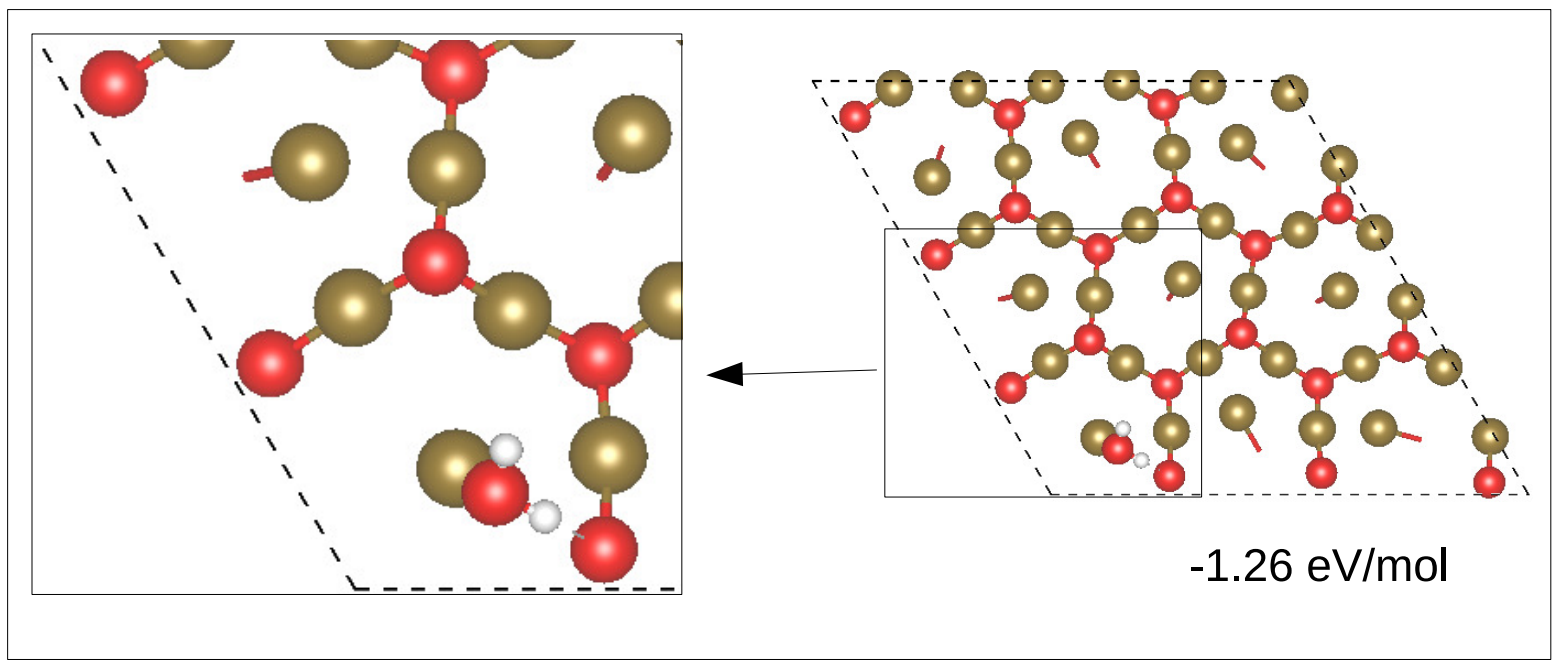

Figure 6: Top view of water molecular adsorption on $\mathrm{Cu}(111) \| \mathrm{Cu}_{2} \mathrm{O}(111)$ at low coverage $\left(0.37 \mathrm{~mol} / \mathrm{nm}^{2}\right)$. 


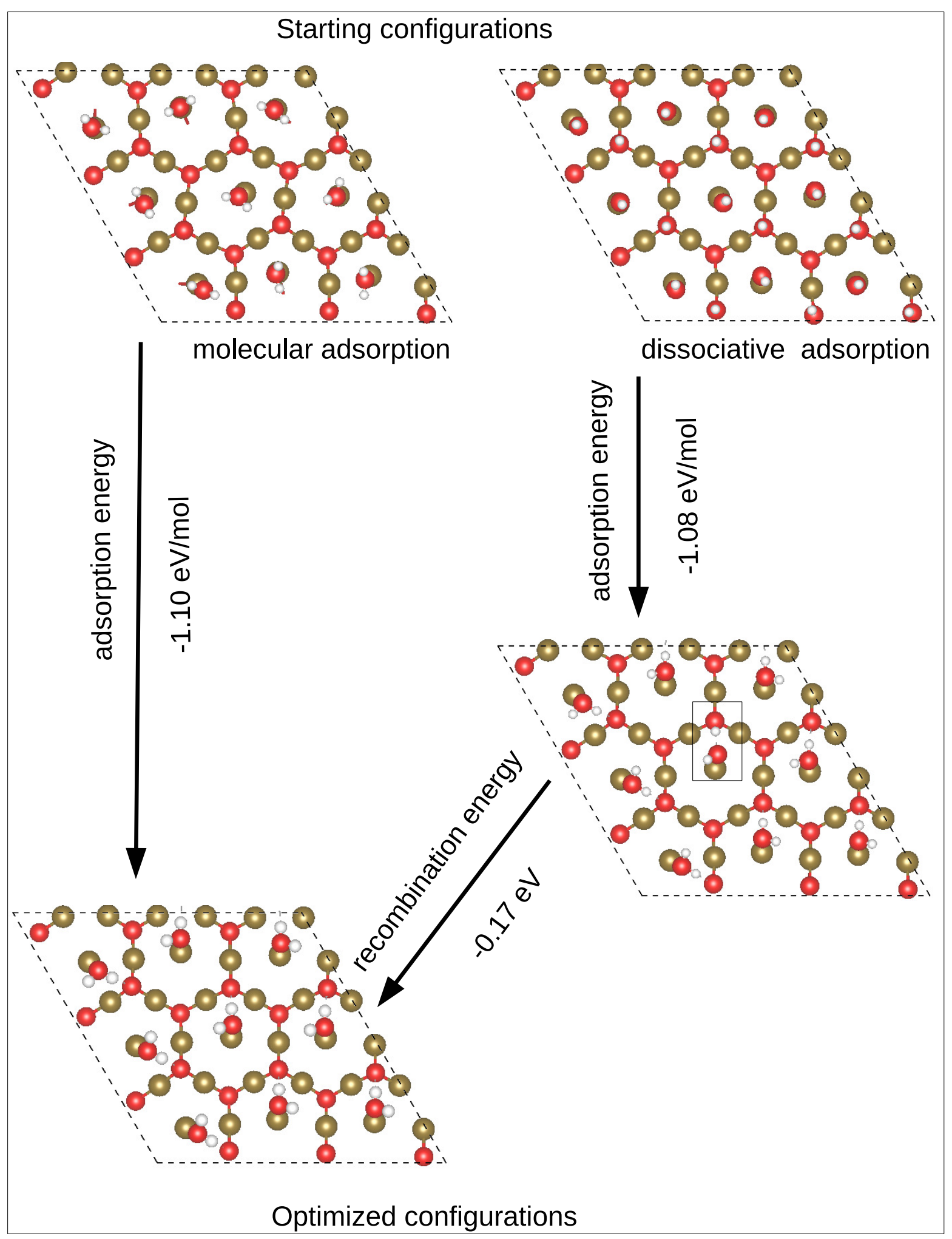

Figure 7: Starting and optimized configurations of molecular and dissociative adsorption of water on $\mathrm{Cu}(111) \| \mathrm{Cu}_{2} \mathrm{O}(111)$ at high coverage $\left(3.27 \mathrm{~mol} / \mathrm{nm}^{2}\right)$. 

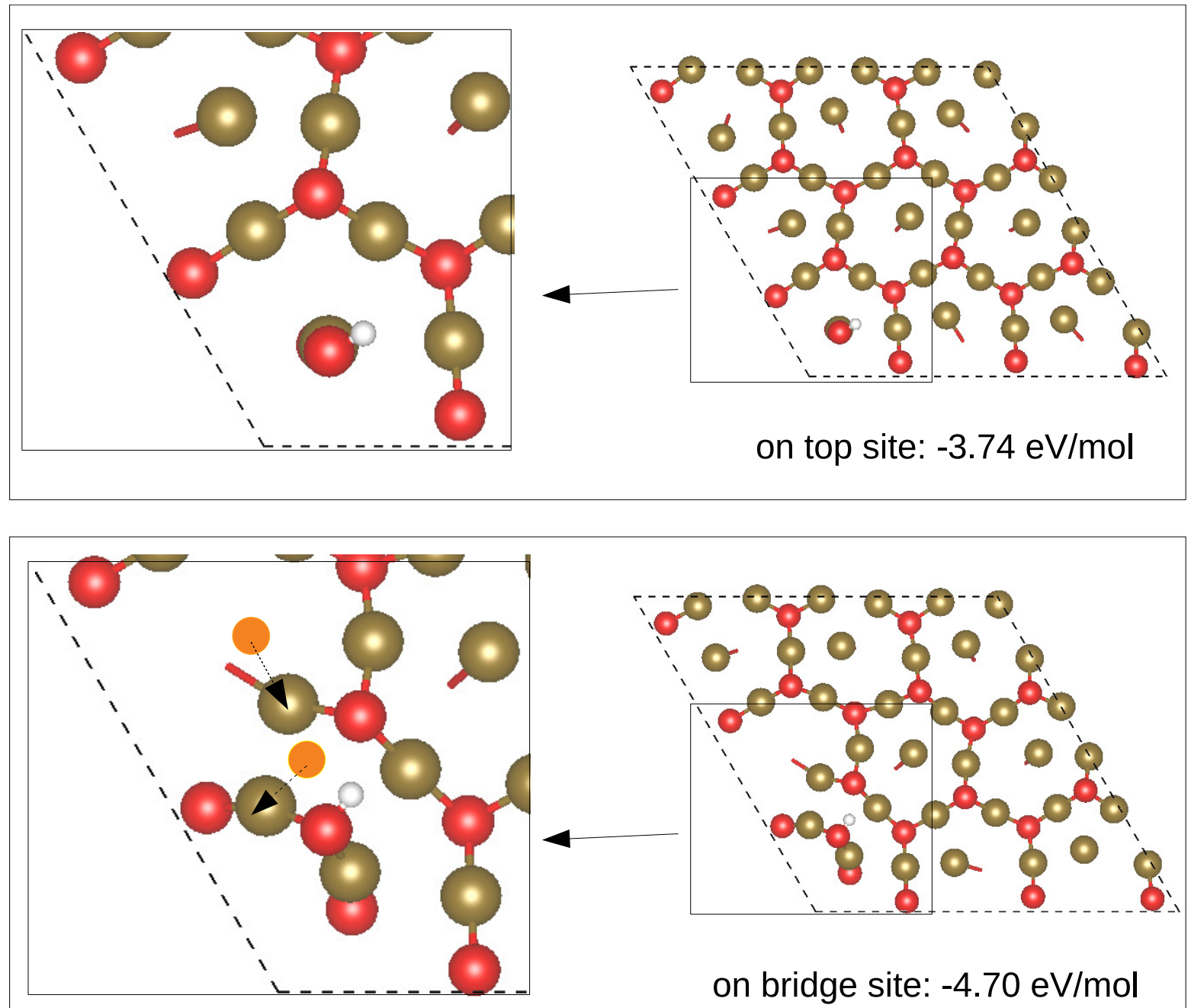

on bridge site: $-4.70 \mathrm{eV} / \mathrm{mol}$

Figure 8: Top view of $\mathrm{OH}^{\circ}$ group adsorbed on $\mathrm{Cu}(111) \| \mathrm{Cu}_{2} \mathrm{O}(111)$ at low coverage $(0.37$ $\mathrm{mol} / \mathrm{nm}^{2}$ ). Top row corresponds to $\mathrm{OH}^{\circ}$ adsorbed on a top $\mathrm{Cu}$ site. Bottom row corresponds to $\mathrm{OH}^{\circ}$ adsorbed on a bridge $\mathrm{Cu}$ site. Circles in zoom area correspond to the $\mathrm{Cu}$ position before adsorption. 


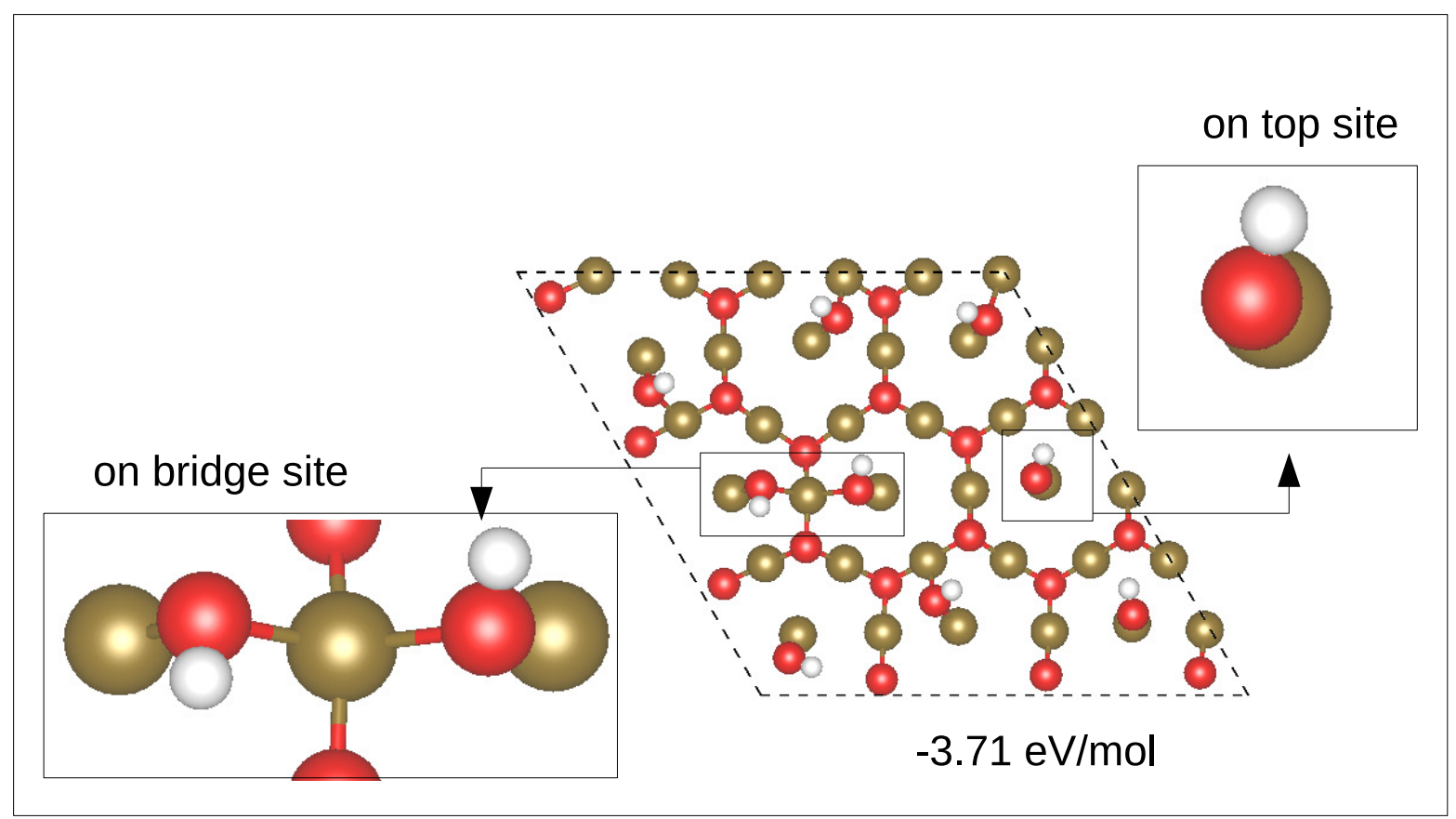

Figure 9: Adsorption of $\mathrm{OH}^{\circ}$ group on $\mathrm{Cu}(111) \| \mathrm{Cu}_{2} \mathrm{O}(111)$ at high coverage $\left(3.27 \mathrm{~mol} / \mathrm{nm}^{2}\right)$. Mixed adsorption mode on a top and bridge sites.

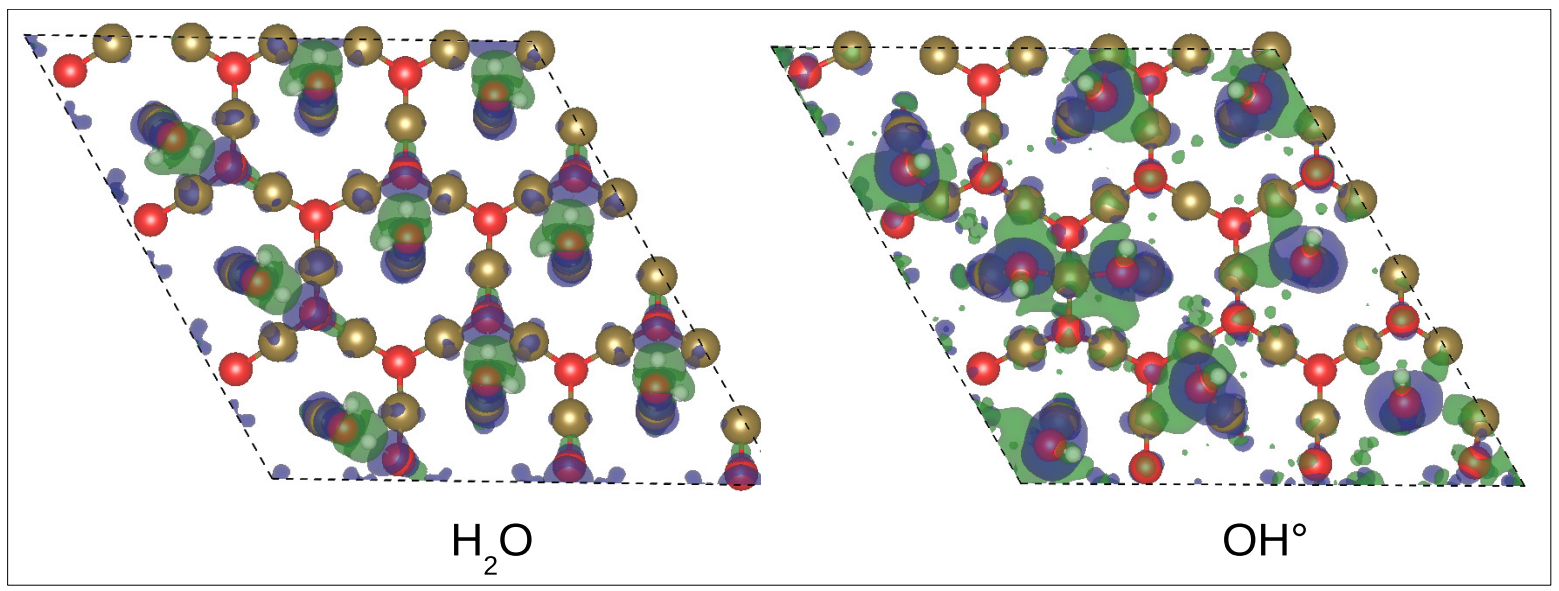

Figure 10: Charge density difference analysis for $\mathrm{H}_{2} \mathrm{O}$ and $\mathrm{OH}$ group adsorbed on $\mathrm{Cu}(111) \| \mathrm{Cu}_{2} \mathrm{O}(111)$ at high coverage $\left(3.27 \mathrm{~mol} / \mathrm{nm}^{2}\right)$. Blue and green color correspond to accumulation and deficit of charge density, respectively 